\title{
Identified Postnatal Mesolimbic Dopamine Neurons in Culture: Morphology and Electrophysiology
}

\author{
Stephen Rayport, David Sulzer, Wei-Xing Shi, ${ }^{a}$ Sansana Sawasdikosol, ${ }^{\mathrm{b}}$ Jacqueline Monaco, Deirdre Batson, \\ and Geetha Rajendranc
}

Departments of Psychiatry, and Anatomy and Cell Biology, and Center for Neurobiology and Behavior, Columbia

University, and Department of Neuropathology, New York State Psychiatric Institute, New York, New York 10032

To examine the intrinsic properties of postnatal mesolimbic dopamine (DA) neurons, we dissociated the ventral tegmental area (VTA) from postnatal rats, enriched for DA neurons by microdissection or gradient purification, and grew the cells in culture. In these cultures, up to $50 \%$ of neurons were dopaminergic. DA neurons resembled their in vivo counterparts in soma shapes, and in showing two levels of tyrosine hydroxylase (TH) expression, axodendritic differentiation, two sizes of synaptic vesicles, nest-like synaptic arrangements with non-DA cells, and synaptic specializations. Electrophysiologically, however, they could not be distinguished from non-DA cells, which could be consistent with heterogeneity in cell properties. To examine a functional subset of VTA DA neurons, we retrogradely labeled VTA neurons projecting to the nucleus accumbens. These mesoaccumbens neurons were $86 \%$ TH positive, $56 \%$ cholecystokinin positive, and $0 \%$ neurotensin positive; they also displayed the soma shapes characteristic of DA neurons more generally and two levels of TH expression. Like their in vivo counterparts, mesoaccumbens cells generally fired single broad spikes that were triggered by slow depolarizations and had robust spike afterhyperpolarizations, lowand high-threshold $\mathrm{Ca}^{2+}$ spikes, rapid accommodation of firing, time-dependent anomalous rectification, and hyperpolarizing autoreceptor responses. Strikingly, the expression of these active properties did not change with time in culture. Mesoaccumbens DA cells could be identified by a distinctive subset of properties that made up an electrophysiological signature; however, unlike their in vivo counterparts, they were less often spontaneously active and never fired in bursts. These results suggest that most DA cell

\footnotetext{
Received Dec. 23, 1991; revised May 22, 1992; accepted May 29, 1992.

We thank Drs. Paul Rosenberg, Robert Baughman, Alan Kay, Robert Wong, James Goldman, Mary Beth Hatten, Amy MacDermott, Charles Kaufmann, and Virginia Pickel for their advice, Lothar Jennes and Peter Kalivas for neurotensin antiserum, Herbert Pardes and Nicholas Willson for their support, and George Aghajanian for his comments on the manuscript. We thank Peter Hilal for software support, and Henry Nelson, Jevons Liu, and Marvin Nalick for technical assistance. This work was supported by the Dana Foundation, BRSG Grant RR05650, NIMH Grants MH00705 and MH44736, and an APA/Wisniewski Research Award (S.R.); and by an NARSAD Young Investigator Award (D.S.).

Correspondence should be addressed to Dr. Stephen Rayport, Columbia University Department of Psychiatry, New York State Psychiatric Institute, Box 62, 722 West 168th Street, New York, NY 10032.

aPresent address: Department of Psychiatry and Physiology, Yale University, New Haven, CT 06510 .

bPresent address: N.I.A.I.D., 12441 Parklawn Drive, Rockville, MD 20852.

'Present address: New York Medical College, Valhalla, NY 10595.

Copyright (c) 1992 Society for Neuroscience $0270-6474 / 92 / 124264-17 \$ 05.00 / 0$
}

properties are intrinsic to the cells, including a significant heterogeneity that is maintained in postnatal culture; their level and mode of activity, however, appear to require afferent input. Culturing identified postnatal VTA DA neurons now makes possible examination of the impact of their individual properties on synaptic function.

The dopamine (DA) neurons in the ventral tegmental area (VTA) that give rise to the mesolimbic projection have aroused particular interest because of their putative involvement in brain reward mechanisms and schizophrenia. In the intact brain, it has been difficult to evaluate the intrinsic properties of these cells because of mutual interactions, multiple inputs, and strong feedback from target areas. One view has been that DA neurons form a relatively homogeneous population replaceable by exogenous DA or transplantation of DA-releasing cells. In fact, the neurons may be rather heterogeneous and this may impact significantly on their function (Sesack and Bunney, 1987; Graybiel, 1990).

Several lines of morphological and physiological evidence point to the heterogeneity of DA neurons in the ventral midbrain. Morphologically, these DA neurons range from multipolar to fusiform in shape (Domesick et al., 1983; Tepper et al., 1987; Grace and Onn, 1989) and vary considerably in size (Domesick et al., 1983; Grace and Onn, 1989; Yung et al., 1991). VTA DA cells differ in levels of tyrosine hydroxylase $(\mathrm{TH})$, with lower levels correlating with more robust inhibitory synaptic input (Bayer and Pickel, 1990, 1991). Cholecystokinin (CCK) is differentially distributed in midbrain DA cells (Seroogy et al., $1987,1988,1989)$. The axons of DA neurons interact with different compartments in striatum and nucleus accumbens (NA), making a diversity of synapses on dendritic spines, dendrites, and cell bodies (Sesack and Pickel, 1990). DA neurons are in turn modulated by distinct, parallel feedback loops (Fallon, 1988; Smith and Bolam, 1990). There are two distinct mesocortical DA innervations, one of which is colocalized with neurotensin (NT) (Febvret et al., 1991). Electrophysiologically, nigrostriatal DA neurons fall into two classes based on their firing pattern, autoreceptor sensitivity, conduction velocity, and rostrocaudal position (Shepard and Gcrman, 1988). They also show two types of low-threshold $\mathrm{Ca}^{2+}$ spikes (LTSs) that do not appear to correlate with cell morphology or location (Yung et al., 1991). However, this variation is not so great that it precludes identification of DA neurons by their electrophysiological properties (Bunney et al., 1973; Wang, 1981; Grace and Bunney, 1983a,b; Llinás et al., 1984; Kita et al., 1986; Lacey et al., 1987, 1988, 1989; Matsuda et al., 1987; Silva et al., 1988, 1990; Grace and 
Onn, 1989; Mueller and Brodic, 1989; Grace, 1990, 1991b; Mereu et al., 1991; Yung et al., 1991).

One way to evaluate functional heterogeneity in different DA cell populations and determine the degree to which their properties depend on afferent input is to examine them in primary culture. Fetal DA neurons have been extensively studied in vitro, where they show the characteristic shapes and transmitter histochemistry (cf. Berger et al., 1982); however, they also show considerable plasticity in transmitter content and axodendritic differentiation (Prochiantz et al., 1979; di Porzio et al., 1980; Rousselet et al., 1988). Electrophysiological studies have been difficult because DA neurons are a small minority in fetal cultures, usually less than 1\% of the neurons (e.g., Heyer, 1984; Chiodo and Kapatos, 1987; di Porzio et al., 1987; Silva et al., 1988). Two groups have provisionally identified DA neurons by appearance (Chiodo and Kapatos, 1987) or by uptake of the fluorescent neurotoxin 5,7-dihydroxytryptamine (Silva et al., 1988) and found that fetal DA neurons show several, but not all, of the characteristic electrophysiological properties (Chiodo and Kapatos, 1987; Silva ct al., 1988). Ovcrall, thesc findings suggest that cultured fetal DA neurons are immature and that their in vitro properties depend significantly on culture conditions.

To examine more mature mesolimbic DA neurons, we developed techniques for the culture of postnatal mesolimbic DA cells. In postnatal rats, brain nuclei are well delineated and DA neurons are somewhat larger than their neighbors, facilitating the preparation of enriched cultures of DA cells as well as retrograde labeling to identify cells based on their projections. We used these advances to examine the morphology and electrophysiological properties of postnatal VTA DA neurons. In culture, these cells reestablish a range of morphological properties including the formation of synapses. Certain electrophysiological properties are distinctive of DA cells while others are more variably expressed.

Portions of this work have appcarcd previously in abstract form (Rayport et al., 1988, 1989, 1990).

\section{Materials and Methods}

VTA cell culture. Rat pups aged 5-7 d (P5-P7) were anesthetized by hypothermia (Phifer and Terry, 1986). Following anatomical landmarks verified from tyrosine hydroxylase (TH) staining, a $2.5 \mathrm{~mm}^{3}$ block containing the VTA was dissected from a parasagittal midbrain slice. This was cut into several smaller pieces and enzymatically dissociated under continuous oxygenation with slow stirring at $32^{\circ} \mathrm{C}$. We used either trypsin (Sigma, type XI; $0.35 \mathrm{mg} / \mathrm{ml}$ ) in a PIPES-buffered saline (Kay and Wong, 1986) or papain (Worthington, $10 \mathrm{U} / \mathrm{ml}$ ) in a bicarbonate-buffered saline (using carbogen) (Huettner and Baughman, 1986, 1988) with comparable results. After $2 \mathrm{hr}$ of incubation, tissue chunks wcrc washed in plating medium (Sigma Minimal Essential Medium Eagle with $10 \%$ Hyclone supplemented-defined calf serum) and triturated 25 times with a wide-bore, fire-polished Pasteur pipette. Undissociated tissue was allowed to settle; the supernatant was collected, and the procedure was repeated twice, combining the supernatants. This yielded a single-cell suspension that was pelleted and then resuspended in plating medium at the desired plating density.

Plates were prepared in advance by attaching polyornithine-coated coverslips under $0.6 \mathrm{~cm}^{2}$ holes in the bottoms of $50 \mathrm{~mm}$ snap-top polystyrene Petri dishes (Falcon) and growing glial fibrillary acidic protein-positive astrocyte monolayers (McCarthy and de Vellis, 1980) to confluence. An individual VTA was distributed into four wells $(80 \mu \mathrm{l} /$ well), yielding cell densities of about 40,000 cells per $\mathrm{cm}^{2}$. Just after plating, most neurons retained processes extending one to two soma diameters that retracted over the course of half an hour. Within $2 \mathrm{hr}$, cells attached and elaborated fine neurites. The remainder of the dish was then flooded with $2.5 \mathrm{ml}$ of SFIC culture medium, which was replaced the following day with fresh medium, containing 5-fluorodeoxyuridine ( $25 \mu \mathrm{M}$, with $70 \mu \mathrm{M}$ uridine) to suppress growth of nonneuronal cells. Cultures were subsequently fed once every 2 weeks by replacing the medium in the dish but not the well. SFIC medium (chemical components from Sigma) was quasi serum-free and contained $47 \%$ Minimal Essential Medium Eagle, 40\% Dulbecco's Modified Eagle's medium, $10 \%$ Ham's F-12 nutrient medium, $4.5 \mathrm{mg} / \mathrm{ml}$ glucose, $0.25 \%$ albumin, $0.5 \mathrm{mM}$ glutamine, $100 \mu \mathrm{g} / \mathrm{ml}$ transferrin, $15 \mu \mathrm{M}$ putrescine, $30 \mathrm{nM} \mathrm{Na} \mathrm{SeO}_{3}, 30 \mathrm{nM}$ triiodothyronine, $25 \mu \mathrm{g} / \mathrm{ml}$ insulin, $200 \mathrm{nM}$ progesterone, $125 \mathrm{nM}$ cortisol, $5 \mu \mathrm{g} / \mathrm{ml}$ superoxide dismutase, $10 \mu \mathrm{g} /$ $\mathrm{ml}$ catalase, and penicillin/streptomycin; $1 \%$ supplemented defined calf serum (Hyclone) was added to assure glial longevity (modified from di Porzio et al., 1980; Rosenberg and Aizenman, 1989).

Enriched cultures. Microdissected VTAs were prepared from $1.5 \mathrm{~mm}^{3}$ cubes taken from within the confines of the VTA. For gradient enrichment of DA cells, cells were layered on top of a $5-15 \%$ continuous Percoll (Pharmacia) gradient, centrifuged for $8 \mathrm{~min}$ at $75 \times \mathrm{g}$, harvested in $1 \mathrm{ml}$ fractions, and the large cell fractions pooled. Assessments of the percentage of DA cells and the sizes of all neurons were made in adjacent high-power fields until $100 \mathrm{DA}$ or non-DA cells were counted. Experiments were repeated a minimum of three times; representative results from single experiments are reported. Cell size (mean diameter) is reported as the mean of the maximum diameter and the diameter at $90^{\circ}$ (to the maximum diameter) of every cell counted.

Retrograde labeling. Mesoaccumbens cells were specifically labeled with discrete nucleus accumbens (NA) injections of red or green fluorescent latex microspheres (Luma-Fluor) (see Fig. 4). Pipettes with 30$40 \mu \mathrm{m}$ tip diameters pulled from $1 \mathrm{~mm}$ fiber-filled microcapillary glass on a Flaming-Brown P-80/PC Micropipette Puller (Sutter) were backfilled with microspheres as supplicd. Pl rat pups were anesthetized by hypothermia; the scalp was reflected and a skull flap was turned. They were then stabilized in a Plasticine mold using a mouth bar and a hook inserted through the foramen magnum, and adjusted to bring lambda and bregma to the same height (cf. Heller et al., 1979; Hoorneman, 1985). We approached the ventrolateral NA from a $30^{\circ}$ angle, at coordinates $1 \mathrm{~mm}$ anterior, $3.5 \mathrm{~mm}$ lateral, and $3.5 \mathrm{~mm}$ ventral to bregma. About $0.1 \mu \mathrm{l}$ of microspheres were injected into the NA with multiple $10 \mathrm{msec}$ positive pressure pulses (General Valve). We waited $5 \mathrm{~min}$ before removing the pipette to reduce backflow along the injection track. After bandaging the incision, pups were warmed and then returned to their mother for the $3-5 \mathrm{~d}$ required for retrograde transport. At death, microsphere placement was confirmed in coronal sections made through the NA and by visualization of retrogradely labeled neurons in the VTA VTA culturcs wcrc prepared from the animals where microsphere injections were localized to the ventral NA (about $60 \%$ of injected animals); all showed discrete VTA labeling.

Histochemistry. DA cells were identified by visualization of either DA or TH. For aldehyde-induced histofluorescence, cultures were immersed in ice-cold SPG solution ( $1 \%$ glyoxylic acid in phosphate-buffered $7 \%$ sucrose, $\mathrm{pH} \mathrm{7.4)} \mathrm{for} 5 \mathrm{~min}$, dried in a laminar flow hood, covered with mineral oil, heated to $95^{\circ} \mathrm{C}$ for $5 \mathrm{~min}$, cooled by replacing the mineral oil, and then examined with fluorescein epifluorescence (De la Torre, 1980). For TH immunohistochemistry, cultures were fixed with $4 \%$ paraformaldehyde in phosphate-buffered saline, permeabilized with $0.1 \%$ Triton, incubated in $\alpha$-TH antiserum (Eugene Tech; diluted 1:1000 to $1: 10,000$ ) overnight at $4^{\circ} \mathrm{C}$, stained using a Vectastain Elite kit (Vector) with diaminobenzidine as the substrate, and counterstained with homatoxylin. Cholecystokinin (CCK) and neurotensin (NT) were visualized similarly, except that cultures were treated for $4 \mathrm{hr}$ with 250 or $500 \mathrm{nM}$ colchicine prior to fixation. $\alpha$-CCK antiserum (Peninsula) was used at 1:500 dilution. $\alpha$-NT antiserum was a generous gift of Dr. L. Jennes (Wright State University) and used at 1:5000 dilution. Specific peptide staining was blocked by preincubation of the appropriate antiserum with $0.5 \mathrm{mM}$ CCK or $1.0 \mathrm{mM} \mathrm{NT}$.

Electron microscopy. We used 5-hydroxydopamine uptake to identify DA neurons at the electron microscopic level (Arluison et al., 1978) Cells were grown on Aclar coverslips (Masurovsky and Bunge, 1968), preincubated in $50 \mu \mathrm{M} 5$-hydroxydopamine overnight, and processed as previously described (Sulzer and Rayport, 1990).

Electrophysiology. Electrophysiological data were obtained mainly from cultures between 7 and $22 \mathrm{~d}$ in vitro (DIV) $(n=36$ mesoaccumbens neurons). An additional group of cells in culture for just 2-6 DIV ( $n=$ 8 mesoaccumbens cells) was also examined; since their active properties did not differ from the first group (see below), the results have been combined. Patch pipettes of about $2 \mu \mathrm{m}$ tip diameter and $5 \mathrm{M} \Omega$ resis- 
A

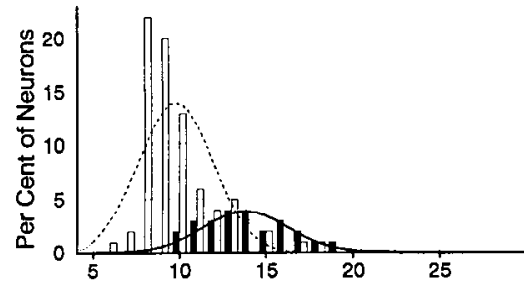

$\mathbf{B}_{1}$

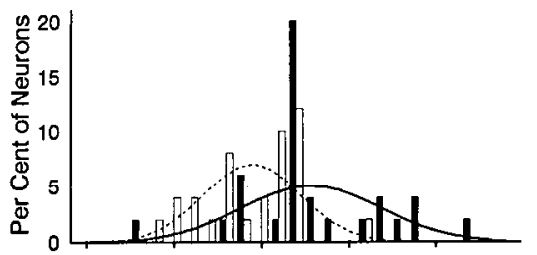

$\mathbf{B}_{2}$

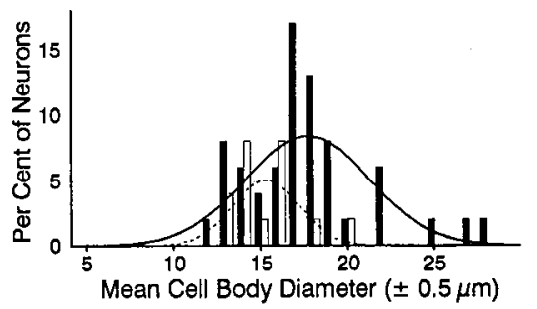

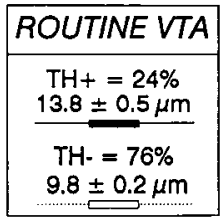
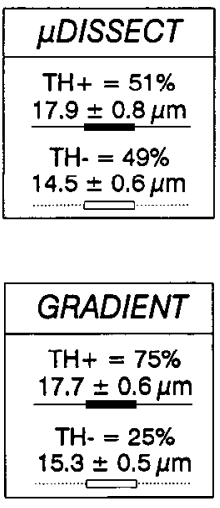

Figure 1. Cell size and DA status in routine and enriched VTA cultures $A$, In a routine postnatal VTA culture $0.5 \mathrm{DIV}, \mathrm{TH}$ staining shows that DA cells $\left(\mathrm{TH}^{+}\right)$constitute $24 \%$ of the neurons (see key). The average diameter of $\mathrm{TH}^{+}$(solid bars) is $140 \%$ that of $\mathrm{TH}^{-}$ncurons. For purposes of companson, normal curves with the mean and SD of each data set are superimposed. $B_{1}$, In a culture 7 DIV made from several microdissected VTAs, $51 \%$ of the neurons are $\mathrm{TH}^{+} . \mathrm{TH}^{+}$neuron diameters are about $115 \%$ of those of $\mathrm{TH}^{-}$neurons. $B_{2}$, With gradient purification of the same cell suspension, the percentage of $\mathrm{TH}^{+}$cells in a sister culture is increased to $75 \%$ of the neurons. At this point, the size distributions completely overlap, precluding further enrichment. Compared to $A$, the diameters of the neurons are larger because of the extended time in vitro.

tance (fabricated on the Flaming-Brown Micropipette Puller) were positioned using Inchworms (Burleigh) mounted on translation stages (Newport). Cultures were maintained at $32^{\circ} \mathrm{C}$ during recording and visualized with modulation-contrast optics. The intracellular solution contained $115 \mathrm{mM} \mathrm{KMeSO}_{4}$ (adjusted to $\mathrm{pH} 7.25$ with $\mathrm{KOH}$ ), $10 \mathrm{mM}$ HEPES, $10 \mathrm{mM}$ BAPTA, $2 \mathrm{mM} \mathrm{MgCl}_{2}, 2 \mathrm{mM}$ ATP, and $100 \mu \mathrm{M}$ leupeptin (Kay and Wong, 1987). The extracellular solution contained $140 \mathrm{mM} \mathrm{NaCl}, 5 \mathrm{mM} \mathrm{KCl}, 2 \mathrm{mM} \mathrm{CaCl}, 2 \mathrm{mM} \mathrm{MgCl}, 25 \mathrm{mM}$ glucose, and $10 \mathrm{mM}$ HEPES, $\mathrm{pH} 7.40$. Voltage signals were recorded with a Dagan 8800 , digitized with an $\mathrm{MI}^{2}$ Interface (Modular Instruments), and analyzed by SPIKE (Hilal Associates). To avoid washout of DA responses, we used the perforated patch technique of Horn and Marty (1988), with a $\mathrm{KCl}$-based intracellular solution without $\mathrm{Ca}^{2+}$ chelators.

The electrophysiological data were compiled from uninjured cells where resting potential, membrane time constant, and action potential shape were stable for a minimum of $15 \mathrm{~min}$. On reaching whole-cell mode, endogenous activity was monitored and the cells were then polarized to $-55 \mathrm{mV}$ to allow comparison of membrane properties; this required only a modest current injection. Spike width was measured as the time from peak to $1 / e$, which closely matched half-amplitude measurements, but was free from the confound of the depolarizing stimulus, which can obscure the rising phase of the spike. Input resistance was measured from the linear range of the $I / V$ curve near rest. Membrane time constant was measured from small hyperpolarizing current pulses; in several cells, the method of peeled exponentials (cf. Grace and Bunney, 1983a) revealed an equalizing time constant $\left(\tau_{0}\right)$ of less than $2 \mathrm{msec}$ and the single membrane time constant reported $\left(\tau_{1}\right)$. Focal drug application was performed with patch pipettes used as puffers and a PicoInjector (Medical Systems).

Statistics. Parametric data are expressed as mean \pm standard error of the mean (SEM); percentages reported are of the total numbers of cells counted. A $\chi^{2}$ analysis (Siegel, 1956) was used to compare the incidence of cell properties to TH status (see Fig. 13), testing if the

frequency of a given cell property differed from that expected if that property were unique to DA neurons. In this analysis, a significant difference implies that the property is not uniquely associated with $\mathrm{TH}$ status, while no significant difference is consistent with the association. To examine changes in the incidence of cell properties with time in culture, we used the Mann-Whitney $U$ test (Siegel, 1956) to distinguish whether there was a significant difference in the time in culture of cells not expressing versus those expressing a given property. Finding no significant difference would be consistent with the lack of an effect due to time in culture, while a significant difference would arise if a property was lost or gained with time in culture.

\section{Results}

\section{Postnatal VTA cell culture.}

Rat DA neurons complete their final divisions almost a week before birth (Altman and Bayer, 1981), and innervate their projection areas shortly thereafter (Voorn et al., 1988). Probably due to this early maturation, postnatal DA neurons do not survive standard fetal cell culture preparation techniques (cf. Ahmed and Fellows, 1987). We found, however, that with acute cell dissociation tcchniques (Kay and Wong, 1986), differing crucially in reduced protease concentration, longer incubation time, continuous agitation, and oxygenation (cf. Huettner and Baughman, 1986, 1988), most DA cells survived. When plated on previously established glial monolayers in a quasi serumfree medium, about $50 \%$ survived the first week, and up to $10 \%$ survived 3 months.

In contrast to fetal midbrain cultures where DA neurons usually comprise $1 \%$ or less of the neurons, about $24 \%$ of the neurons in our routine postnatal VTA cultures were TH-positive $\left(\mathrm{TH}^{+}\right)$DA neurons. Microdissection within the boundaries of the VTA yielded cultures where up to $50 \%$ of the neurons were dopaminergic (cf. Masuko et al., 1986, 1989). Since $\mathrm{TH}^{+}$neurons were larger than $\mathrm{TH}$-negative $\left(\mathrm{TH}^{-}\right.$) neurons (Fig. $1 A$ ), we also used sizing gradients to enrich cultures for DA neurons; these techniques could be combined to yield up to $75 \% \mathrm{DA}$ ncurons (Fig. $1 B$ ), although ccll numbers were low. Separately, microdissection and gradient purification yielded cultures with similar percentages of DA neurons, so results from these two methods were combined.

\section{Postnatal VTA DA cells in general}

Cellular morphology. $\mathrm{TH}^{+}$cells in enriched cultures elaborated extensive arrays of TH' neurites (Fig. $2 A$ ), which could be tentatively classified either as dendritic or axonal. Several thicker dendrite-like processes emerged from the cell body; they tended to vary in diameter along their length and terminated within about $200 \mu \mathrm{m}$ of the cell body. In contrast, a single thin, axonlike process emerged from the cell body or from a proximal dendrite-like process and maintained a uniform diameter for hundreds of microns before it branched and exhibited varicosities. These varicosities, unlike the expansions of dendrite-like processes, were often associated with the cell bodies and proximal processes of non-DA cells (Fig. $2 A, B$ ), resembling nest-like synaptic arrangements observed in the intact VTA (cf. Oades and Halliday, 1987). Comparing $\mathrm{TH}^{+}$cells in a given culture invariably showed a significant gradation in the intensity of TH immunostaining from darkly stained to lightly stained neurons, consistent with the two levels of TH staining observed in the intact brain (cf. Bayer and Pickel, 1990).

Ultrastructure of DA neurons. We used 5-hydroxydopamine, which is specifically accumulated in catecholaminergic vesicles and produces an electron-dense reaction product, to identify DA neurons (cf. Arluison et al., 1978). In the cell body, axon, 

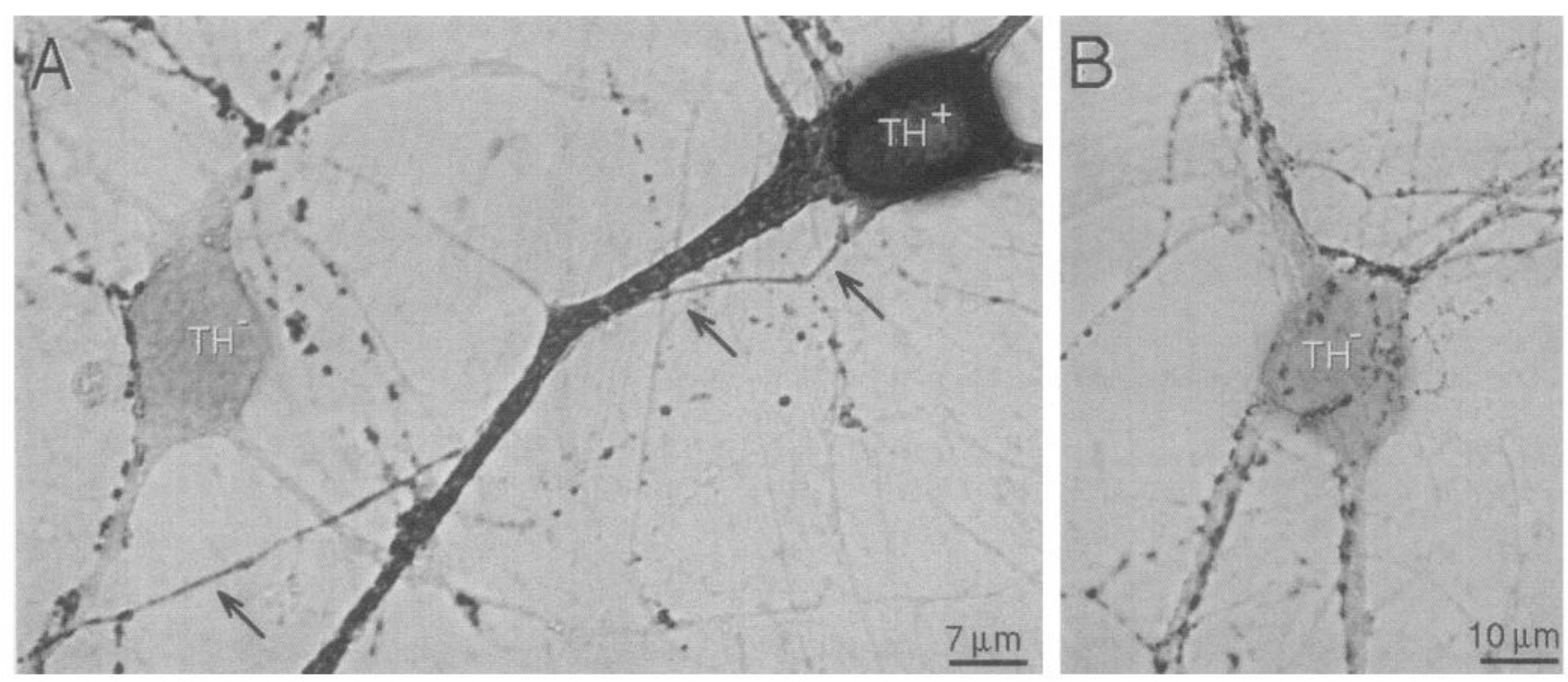

Figure 2. Putative DA synapses in VTA cultures. A, DA neurons $\left(\mathrm{TH}^{+}\right)$elaborate several dendrite-like processes and a single axon-like process (arrows), in a culture 24 DIV. Other cell bodies $\left(\mathrm{TH}^{-}\right)$invariably appear raised above the glial layer and are reliably classified by visual criteria as neurons (as confirmed electrophysiologically). The axon-like process gives rise to several branches that are studded with varicosities over a $\mathrm{TH}^{-}$ neuron, which they invest in a nest-like contact. $B$, In a culture $21 \mathrm{DIV}$, another nest-like contact is seen between $\mathrm{TH}^{+}$axon-like processes from a distant cell (out of the frame) with a $\mathrm{TH}^{-}$neuron. These frequently seen interactions suggest that $\mathrm{TH}^{+}$cells make synaptic contacts with other VTA neurons.

and axon terminals, we observed two populations of electrondense vesicles, circular vesicles about $40-50 \mathrm{~nm}$ in diameter and moderately pleomorphic vesicles about $100 \mathrm{~nm}$ in diameter. Control preparations never showed small, electron-dense vesicles, nor did the staining of larger dense-core vesicles approach the intensity of staining in the 5-hydroxydopamine-treated cultures. The fraction of cells labeled roughly matched the fraction of DA cells in sister cultures. Many of the 5-hydroxydopaminelabeled cells showed a characteristic profile: they were oval with radially oriented processes and an eccentrically placed nucleus with a prominent nucleolus (see below).

The cell bodies of DA neurons were identified by stained vesicles clustered near the soma perimeter (shown in Fig. 1 of Sulzer and Rayport, 1990). Proximal dendrites emerging from labeled cells showed numerous polyribosomes, but did not contain stained vesicles. In addition to a robust compliment of polyribosomes, cell bodies showed a prominent Golgi apparatus, infrequent lamellar bodies, and microtubule arrangements suggestive of cilia (not shown), as has been seen in TH-stained DA cells in the intact VTA (Domesick et al., 1983; Bayer and Pickel, 1990). Labeled axonal processes, marked by microtubules, were often found in close proximity, forming fascicles (Fig. $3 A$ ). Axonal processes gave rise to varicosities containing numerous mitochondria and clusters of vesicles (Fig. $3 B$ ). These clusters often apposed dendritic processes, marked by the presence of polyribosomes. Clusters of vesicles at synaptic specializations were occasionally seen (Fig. $3 C$ ). These ultrastructural observations confirm that postnatal DA neurons elaborate dendrites and axons. Furthermore, they synapse with other cells in culture, as suggested by our light microscopic observations.

Identification of DA cells in enriched cultures. $\mathrm{TH}^{+}$cells in enriched cultures had four shapes, as did the subset of mesoaccumbens cells (see below). However, even when examining only the largest cells (see above) or those with the most common oval eccentric-nucleus shape (see below), we could not distinguish DA cells on electrophysiological grounds. This might be either due to a previously unappreciated heterogeneity in the electrophysiological properties of VTA DA neurons, or because the properties of non-DA neurons in the cultures are not so different. Thus, microdissection or gradient purification provided a readily achieved enrichment in DA neurons, but not one sufficient to identify DA neurons without histochemical processing.

\section{Mesoaccumbens DA cells}

To increase our ability to identify living DA neurons and to focus on a single mesolimbic projection, we injected red or green fluorescent latex microspheres (Katz et al., 1984; cf. Huettner and Baughman, 1986, 1988) into the ventral NA of P1 rat pups. Retrograde labeling became apparent in the midbrain by $\mathrm{P} 3$ and reached maximum levels by $\mathrm{P} 4$. On P5-P7, we prepared routine VTA cultures. We made routine-as opposed to enrichedVTA cultures with the aim of comparing the properties of microsphere-labeled neurons to other neurons in the same dishes, which we refer to as VTA neurons. We confirmed the accuracy of all injections in coronal sections through the NA at the time of culturing (Fig. $4 A$ ); invariably, NA injections were associated with retrograde labeling in the VTA, seen immediately superior to the midbrain flexure (Fig. $4 B$ ). Less intense labeling was apparent in the substantia nigra and the region of the rostral and central linear nuclei. After dissociation, labeled cells could be easily identified under epifluorescence (Fig. $4 C$ ).

It should be noted that because of the limited spread of microspheres at the injection site, only a fraction of mesoaccumbens cells were labeled. We estimate that in each VTA culture dish containing 20,000 neurons, about $24 \%$ were dopaminergic. Considering the $50 \%$ of DA cells ipsilateral to the injection site, and given that one-third of DA VTA cells project to the accumbens (Swanson, 1982), about 800 cells per dish should be mesoaccumbens DA cells. Since we found about 25 microspherelabeled cells in a dish, retrograde labeling from the NA identified about $3 \%$ of ipsilateral, DA mesoaccumbens cells. Considerably 

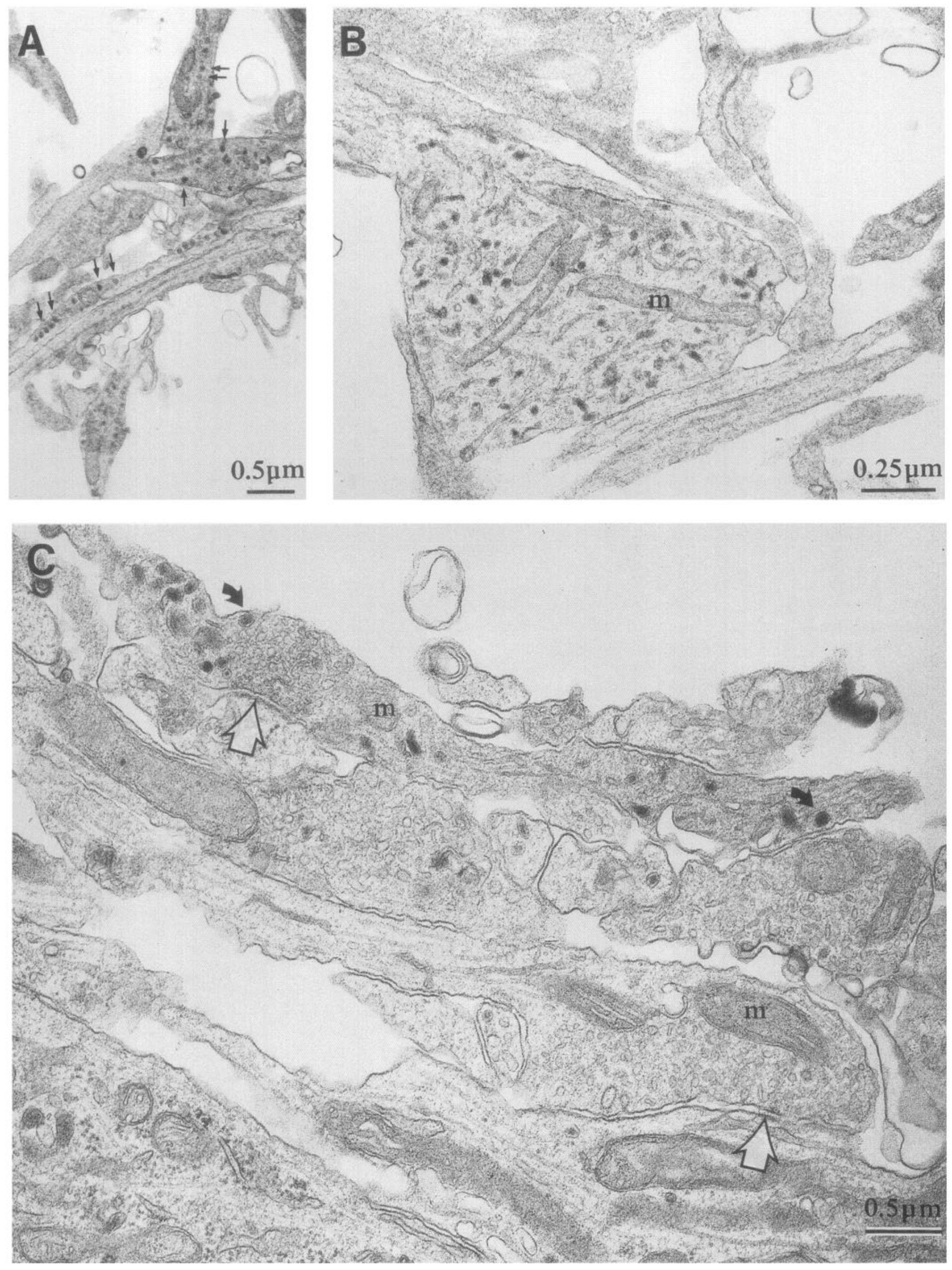

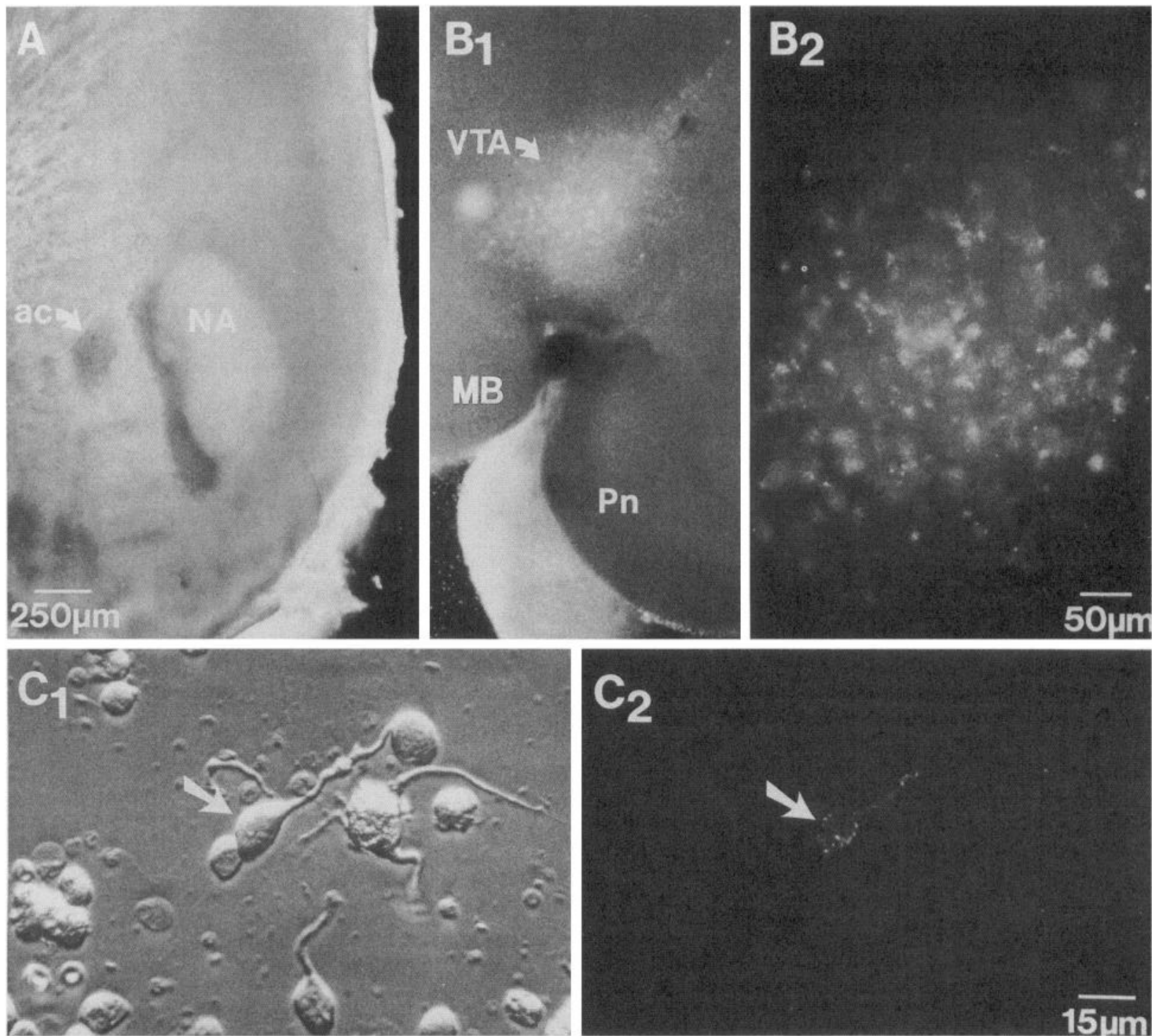

Figure 4. Identification of mesoaccumbens cells. $A$, The NA of rat pups was stereotaxically injected with about $0.1 \mu 1$ of fluorescent latex microspheres on P1. On P5, a coronal section (lateral is to the left, dorsal to the top) through the NA shows the delimited injection of microspheres principally in the ventral NA, medial to the anterior commissure $(a c)$. $B_{l}$, A sagittal cut $1.5 \mathrm{~mm}$ lateral to the midline and tangential to the VTA, examined with epifluorescence, shows microsphere-labeled cells in the VTA. Labeled mesoaccumbens cells form a distinctive cluster above the midbrain flexure ( $P n$, pons; $M B$, mammillary body). Scale is as in $A . B_{2}$, At higher magnification of the VTA, punctate cellular labeling is apparent and proximal processes can be discerned. $C_{l}$, After cell dissociation, process-bearing cells are isolated (modulation-contrast optics). $C_{2}$, The same field under epifluorescence shows one microsphere-labeled, mesoaccumbens cell (arrows in $C_{I}$ and $C_{2}$ ). Microsphere-labeled cells are 86\% dopaminergic.

more cells were retrogradely labeled with fluorogold or diI (prepared in soluble form); however, the DA fraction dropped to about $50 \%$, similar to the DA fraction in instances where microspheres spread outside the NA. Although only a minority of mesoaccumbens cells were labeled in any one animal, the VTAs from several animals were pooled in each set of cultures, and the results presented are derived from over 200 animals with injections covering the entire ventral NA.

As previously reported (cf. Fig. 15 of Hökfelt et al., 1980; Swanson, 1982), we found that most retrogradely labeled cells in frozen sections through the VTA were $\mathrm{TH}^{+}$(not shown). In VTA cultures, $86 \%$ of retrogradely labeled cells were $\mathrm{TH}^{+}(n=$

Figure 3. Ultrastructure of DA cells identified by 5-hydroxydopamine staining. The cell bodies of stained cells often have an eccentric nucleus and dense polyribosomes; vesicles are characteristically located along the cell perimeter, beneath the plasmalemma (shown in Fig. 1 of Sulzer and Rayport, 1990). The axons, but not the dendrites, of DA cells show electron-dense vesicle staining. $A$, DA cell axons fasciculate. Here, three DA axons, identified by electron-dense vesicles (small arrows), run together. Three unlabeled axons are also present. $B$, An axonal process expands into a varicosity marked by many electron-dense vesicles and mitochondria $(m)$. $C$, Within the neuropil of the culture, two synaptic appositions are shown (large, open arrows). The synapse made by the labeled process (upper left) is asymmetric with a postsynaptic specialization; the non-DA synapse (bottom right) is symmetric with pleomorphic vesicles. Two sizes of labeled synaptic vesicles are seen: small vesicles about $40 \mathrm{~nm}$ in diameter (identified in $A$ by small arrows) and large vesicles about $100 \mathrm{~nm}$ in diameter (C, solid, curved arrows). 

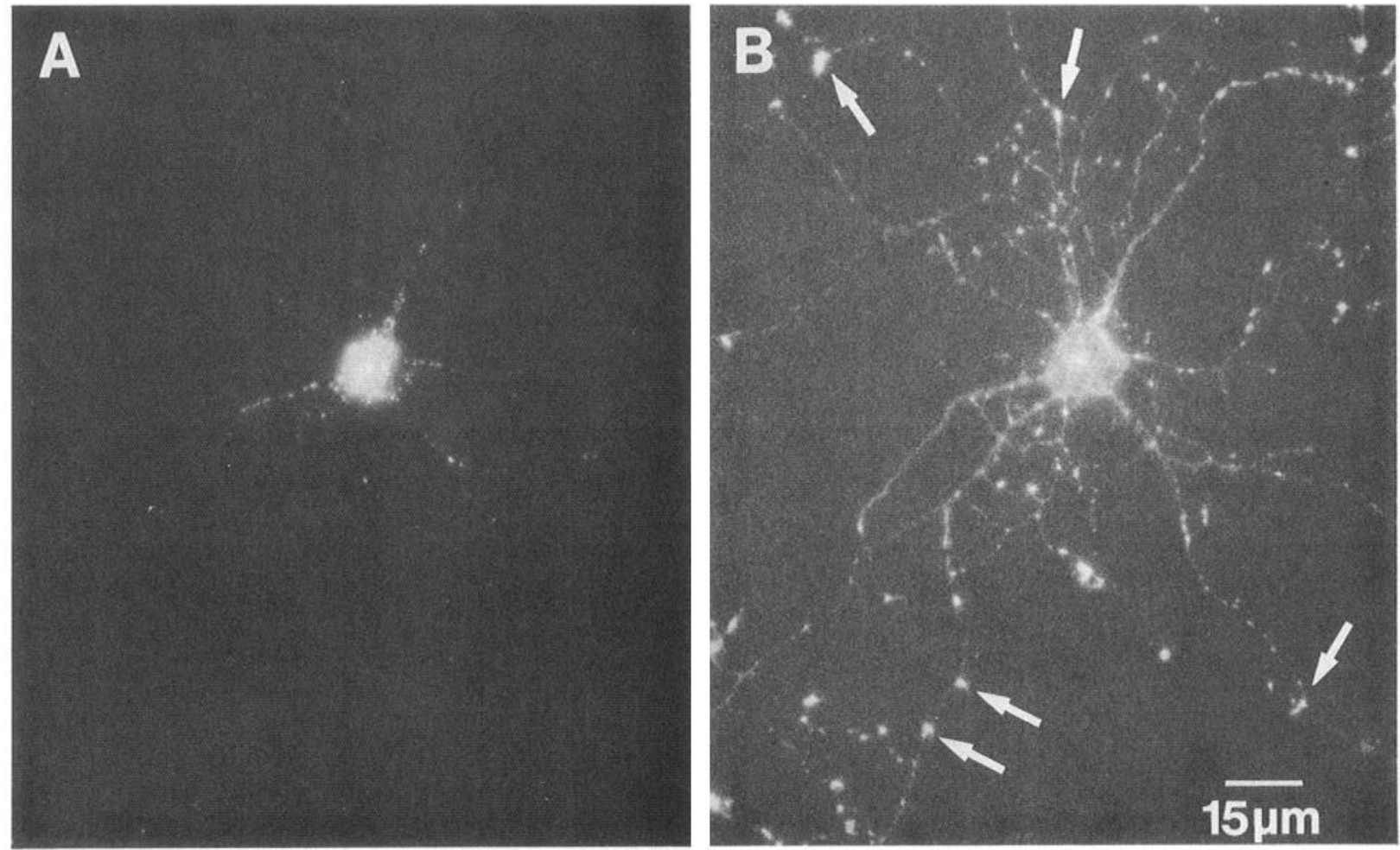

Figure 5. DA staining of mesoaccumbens cells: aldehyde-induced histofluorescence in a culture 10 DIV. A, Rhodamine epifluorescence shows a single red microsphere-labeled, mesoaccumbens cell. B. Fluorescein epifluorescence of the same cell shows green, glyoxylic acid-induced DA fluorescence. Several major dendrites with numerous dendritic branches are revealed; these are studded with varicosities (arrows). Axons do not show histofluorescence.

300). This percentage was constant in cultures fixed at $2 \mathrm{hr}$ to 2 weeks in vitro, suggesting that there was no differential survival of DA and non-DA cells (cf. Yamamoto et al., 1981). Microsphere labeling was most intense during the first week in culture, when microspheres were seen in both the cell body and proximal processes (Fig. $5 \mathrm{~A}$ ); in older cultures, microsphere labeling grew fainter and was confined to the cell body region. There was no deleterious effect of microsphere labeling (cf. Divac and Mogenson, 1990) nor evidence of photodynamic damage with ex- tended fluorescence excitation. We further confirmed the transmitter status of microsphere-labeled cells by aldehyde-induced histofluorescence, which showed that most mesoaccumbens neurons were dopaminergic. Similar to the subcellular distribution of TH in DA cells, aldehyde-induced histofluorescence was seen in cell bodies and in dendrite-like processes, which were studded with varicosities (Fig. $5 B$, arrows). However, in contrast to the TH subcellular distribution, axon-like processes were not seen.
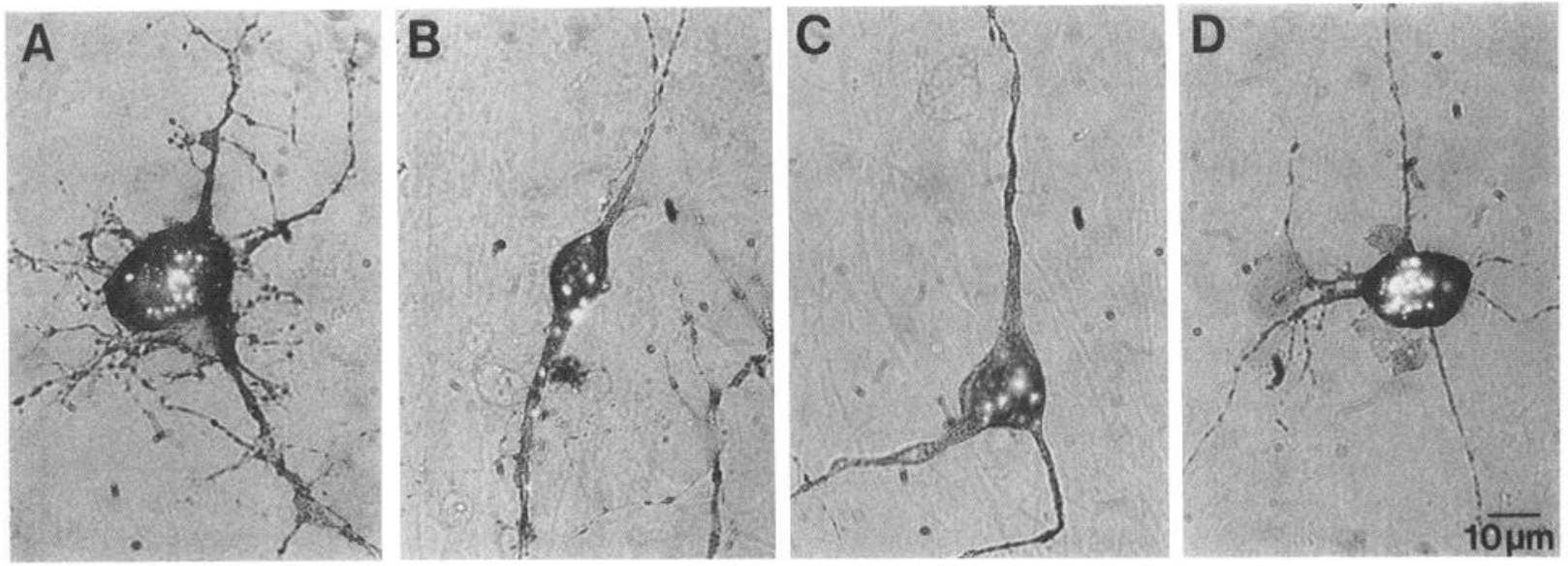

Figure 6. Shapes of mesoaccumbens DA cells. After 7 DIV, mesoaccumbens cells were immunostained for TH. Mesoaccumbens DA cells show four distinctive shapes, in decreasing frequency: large, elliptical, with eccentric nucleus $(A)$; medium sized, fusiform $(B)$; medium sized, pyramidal $(C)$; or medium to small sized, spherical $(D)$. Two levels of TH staining are seen: compare the lighter-staining pyramidal cell $(C)$ with the other cells. There is no relationship between level of staining and cell shape. 

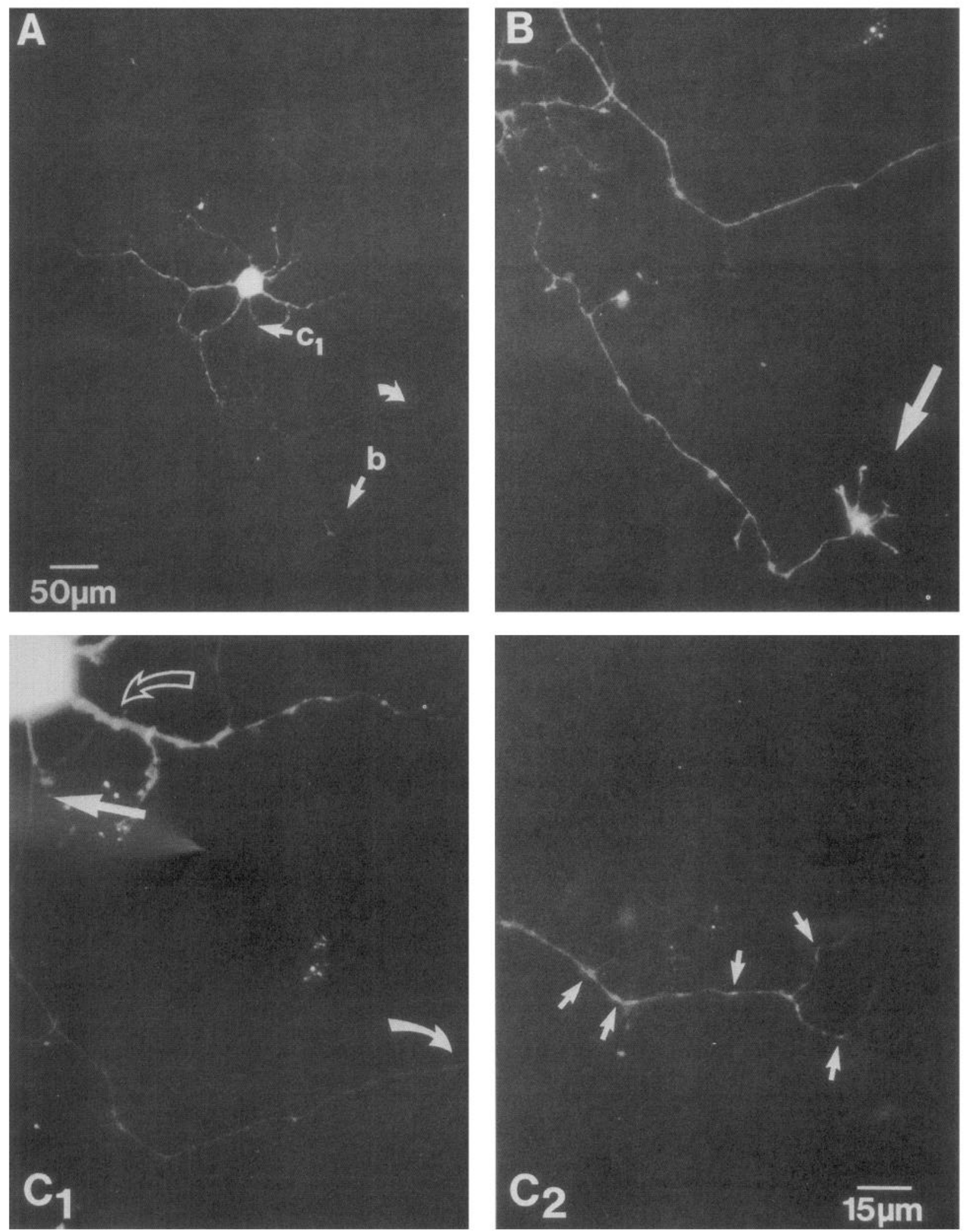

Figure 7. Lucifer yellow fill of an eccentric nucleus mesoaccumbens cell. After 16 DIV, a microsphere-labeled mesoaccumbens cell is filled with Lucifer yellow $(0.5 \%)$ from a patch pipette. $A$, The cell body gives rise to six major dendrite-like processes, and one axon-like process (arrow $c_{l}$ marks the initial segment and is shown at higher magnification in $\left.C_{l}\right)$. The axon-like process bifurcates below the cell body into one branch terminating in a growth cone ( $b$, shown at higher magnification in $B$ ) and another that extends (curved arrow) beyond the right side of the plate (its final extent is shown in $C_{2}$ ). $B$, The axon branch with a growth cone (arrow; labeled $b$ in $A$ ) is seen at higher magnification (scale same as in $C$ ). $C_{l}$, The initial segment of the axon-like process (solid, straight arrow, labeled $c_{l}$ in $A$ ) and one proximal dendrite-like process (open, curved arrow) emerge from the cell body. The axon-like process (solid, curved arrow) is smooth, thin, and of uniform diameter as compared with the dendritelike process, which is thicker and varied in diameter. $C_{2}$, The other branch of the axonal bifurcation (labeled with curved arrow in $A$ ) gives rise to a longer branch, running over $1000 \mu \mathrm{m}$, which ends in neurites studded with varicosities (arrows). 


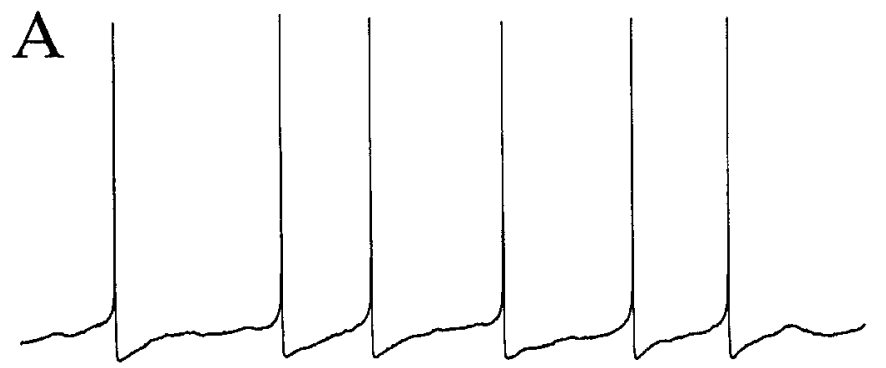
$500 \mathrm{~ms}$

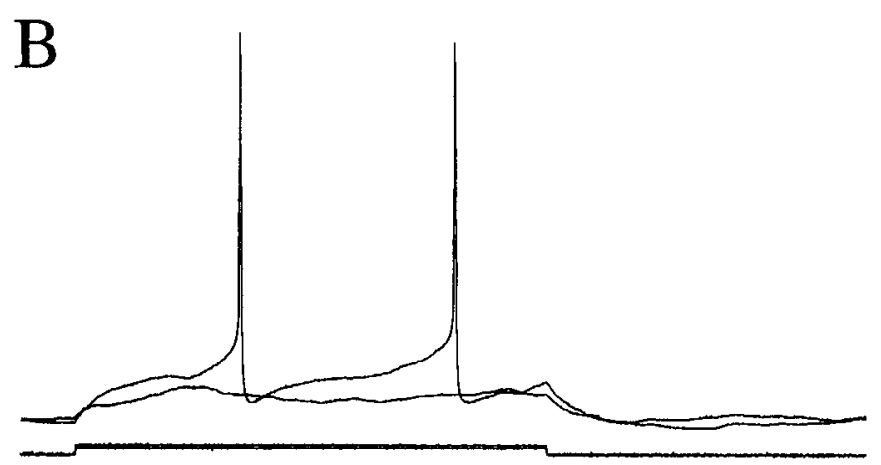

$30 \mathrm{mV}$

$0.15 \mathrm{nA}$

$150 \mathrm{~ms}$

Figure 8. Intrinsic electrical activity in mesoaccumbens cells. $A$, Spontaneous activity. About $11 \%$ of mesoaccumbens cells were spontaneously active. In this cell (22 DIV), slow depolarizations precede single spike firing. Each spike ends in a long hyperpolarizing afterpotential, followed by brief period at rest, and another slow depolarization, which triggers the subsequent spike. Cells never showed burst firing. $B$, Induced rhythmic activity. In a silent mesoaccumbens cell (7 DIV), two sweeps with differing levels of current injection are superimposed. Low levels of depolarizing current injection elicit slow depolarizations; slightly greater depolarizing current injection leads to pacemaker activity with spikes apparently triggered by the slow depolarizations. There is no relationship between time in culture and spontaneous activity.

TH staining. $\mathrm{TH}^{+}$mesoaccumbens cells showed four characteristic soma shapes (Fig. 6). In order of incidence, cells were large, oval with a characteristically placed eccentric nucleus and multipolar (Fig. 6A), smaller and fusiform (Fig. 6B), pyramidal (Fig. 6C), or medium to small and spherical (Fig. 6D). None of these shapes was sufficiently distinctive to identify the neurons as dopaminergic, nor were they associated with particular electrophysiological properties. A similar range in cell shapes was seen in cultures processed for aldehyde-induced histofluorescence (not shown). These observations suggest that the range in morphologies of mesoaccumbens DA neurons is similar to that of the larger set of VTA DA neurons.

Cotransmitter status. Mesoaccumbens cells were $55 \% \mathrm{CCK}$ positive $\left(\mathrm{CCK}^{+}\right)$, whereas VTA neurons (cells that were not microsphere labeled in the same dishes) were $5 \% \mathrm{CCK}^{+}$. This gives a $\mathrm{CCK}^{+}: \mathrm{TH}^{+}$cell ratio of 0.63 for mesoaccumbens cells, as compared to 0.20 for VTA cells (summarized in Fig. 13, below), demonstrating that CCK was mainly colocalized with DA in cultured mesoaccumbens cells. The oval, eccentric nucleus profile was most prevalent among $\mathrm{CCK}^{+}$mesoaccumbens cclls. NT immunoreactivity was excluded from mesoaccumbens cells, although it was present in $4 \%$ of VTA cells.
Axodendritic differentiation. We filled single mesoaccumbens cells with Lucifer yellow to examine their processes. Invariably, one axon-like process and several dendrite-like processes arose from the cell soma (Fig. $7 A$ ). Dendrites were confined to the immediate vicinity of the cell body, extending over $200 \mu \mathrm{m}$, while axons often extended over $1000 \mu \mathrm{m}$, sometimes ending in growth cones (Fig. $7 B$ ). Both dendrites and axons showed varicose expansions, which were present over the full length of the dendrites (Fig. $7 C_{1}$ ), but only distally on axons (Fig. $7 C_{2}$ ). This pattern resembled that seen with aldehyde-induced histofluorescence (Fig. $5 B$ ) and TH staining (Figs. 2A, 6). Considered together with the ultrastructural observations, these results confirm that postnatal mesoaccumbens cells manifest an axodendritic differentiation in vitro.

\section{Electrophysiology of mesoaccumbens cells}

We recorded from 44 microsphere-labeled mesoaccumbens cells (in 21 cultures) and 24 unlabeled VTA cells (in 13 cultures), 222 DIV. About $11 \%$ of mesoaccumbens cells were spontaneously active (Fig. 8A). This low level of spontaneous activity was not due to our recording technique since in several cells subsequently found to be silent, no spontaneous activity was recorded extracellularly (in cell-attached mode) prior to rupturing into whole-cell mode; furthermore, recordings at $37^{\circ} \mathrm{C}$ showed no greater incidence of spontaneous activity (cf. Grace and Onn, 1989). However, low-frequency firing could be elicited in most mesoaccumbens cells with a modest tonic depolarizing current injection, which resembled the firing of the occasional spontaneously active cell (Fig. $8 B$ ). As in more intact preparations, cells fired slowly with slow depolarizations preceding fullsize spikes followed by prominent hyperpolarizing afterpotentials. After these decayed, cells transiently reached the resting level before a slow depolarization triggered another spike. When active or activated by depolarization, cells fired in a regular, single spike or pacemaker mode, but never in bursts.

Passive properties. The mean resting potential measured immediately on achieving whole-cell mode was $-56 \pm 1.0 \mathrm{mV}$, matching results in slice (cf. Grace and Onn, 1989; Mereu et al., 1991). For all subsequent measurements, we adjusted the membrane potential to $-55 \mathrm{mV}$ with a small tonic current injection to assess membrane properties from the same resting level. Measured from small hyperpolarizing steps (from -55 $\mathrm{mV}$ ), cell input resistance decreased moderately with time in culture; the least-squares line in a plot of input resistance versus DIV dropped from 1027 to $655 \mathrm{M} \Omega$; on average, the input resistance measured $900 \pm 120 \mathrm{M} \Omega(n=14)$. Similarly, the time constant dropped from 43.4 to $33.2 \mathrm{msec}$; on average, it measured $40 \pm 5 \mathrm{msec}$ (in the same 14 cells), giving a cell capacitance of $44 \mathrm{pF}$. The passive properties of unlabeled cells were not significantly different.

Active properties. The incidence of cell properties is summarized in Figure 13, below. Mann-Whitney $U$ tests showed that cells expressing each given active property (spontaneous activity, accommodation, anomalous rectification, latency, LTS, and DA response) did not differ significantly in their distribution of times in culture from cells not expressing the property $(p>$ 0.15 ). This demonstrated strikingly that the expression of active properties did not change with time in culture.

To examine individual spikes, microsphere-labeled mesoaccumbens cells were stimulated from rest with short, just-threshold depolarizing current steps (Fig. 9). Peak spike amplitudes measured $98 \pm 1.6 \mathrm{mV}(n=44)$, giving an overshoot of 43 
$\mathrm{mV}$. Action potential width, measured from the peak to $1 / e$ of peak amplitude, was $1.3 \pm 0.1 \mathrm{msec}(n=44)$, matching DA spike width in vivo or in slice (our measurements of spike width using this technique from published data in Grace and Bunney, 1983a; Lacey et al., 1989; Grace, 1990; Yung et al., 1991). About $20 \%$ of mesoaccumbens cells had particularly broad spikes (widths greater than $1.5 \mathrm{msec}$ ) with distinct shoulders, as evidenced by a double inflection in the time derivative of the falling phase of the spike (Fig. 9). In intact preparations, DA cell spike widths are broader than those of adjacent cells; in culture, however, VTA cells spike widths were $1.4 \pm 0.1 \mathrm{msec}(n=24)$, making their spikes as broad as those of mesoaccumbens cells. Based on spikc width, there was no evidence for two cell populations, as we did not find a bimodal distribution of either mesoaccumbens or VTA cell spike widths. To examine this further, we classified spikes as broad by making the assumption that only DA cells had broad spikes. In the distribution of mesoaccumbens cell spike widths, $86 \%$ were broader than $0.8 \mathrm{msec}$; by this criterion, $100 \%$ of VTA cell spikes were broad (had widths greater than $0.8 \mathrm{msec}$ ). Broad spikes of VTA cells might result from the inclusion in the preparation of nearby but not immediately adjacent cells with broad spikes. Slightly narrower spikes of mesoaccumbens cells may reflect the contribution of non-DA mesoaccumbens cells with narrow spikes (Thierry et al., 1980).

Most mesoaccumbens cells showed hyperpolarizing spike afterpotentials ( 37 of 44 ), averaging $-4.7 \pm 0.7 \mathrm{mV}$ in amplitude and $78.5 \pm 7.5 \mathrm{msec}$ in duration (measured from the peak of the spike to the return to baseline). Several cells ( 5 of 44) showed additional afterpotentials that were likely recurrent postsynaptic potentials (PSPs) (not shown). While long-duration, hyperpolarizing afterpotentials were found in the same proportion of mesoaccumbens cells as were dopaminergic, they were also commonly found in VTA cells (15 of 24). Negative afterpotentials were slightly larger and found more often in mesoaccumbens cells, but they were not distinctive enough to identify those cells as dopaminergic.

In most mesoaccumbens cells ( 15 of 26 cells where examined), a train of 5-10 spikes of diminishing amplitude and increasing width was elicited with strong, maintained depolarizations (Fig. $10 A_{l}$ ). Rapid accommodation was seen more commonly in mesoaccumbens than unlabeled VTA cells, which continued to fire regularly for the duration of the depolarization (not shown). Following accommodation, slow undulations of the membrane potential at about the frequency of the preceding spike firing were seen. However, when cells were hyperpolarized by $20 \mathrm{mV}$ and then step depolarized to just above threshold, they gave a distinctive response (Fig. 10 $A_{2}$ ). Mesoaccumbens neurons did not fire immediately, but showed an initial small-amplitude depolarization (26 of 30), followed about $100 \mathrm{msec}$ later by firing. This latency between the small-amplitude depolarization and the initiation of firing (19 of 26 cells) may be due to the transient activation of $I_{\mathrm{A}}$ when its steady-state inactivation is removed by the preceding hyperpolarization (cf. Grace, 1990; Yung et al., 1991). As was also seen with depolarization from rest, spikes diminished in amplitude, increased in width, and often accommodated after 5-10 spikes.

Often the low-amplitude depolarization could be elicited in an all-or-none fashion with just-threshold depolarizations, suggesting that it was an LTS. It persisted in the presence of TTX (not shown), but was blocked when $\mathrm{Ca}^{2+}$ influx was transiently blocked by local perfusion with $\mathrm{Ca}^{2+}$-free saline containing $\mathrm{Cd}^{2+}$

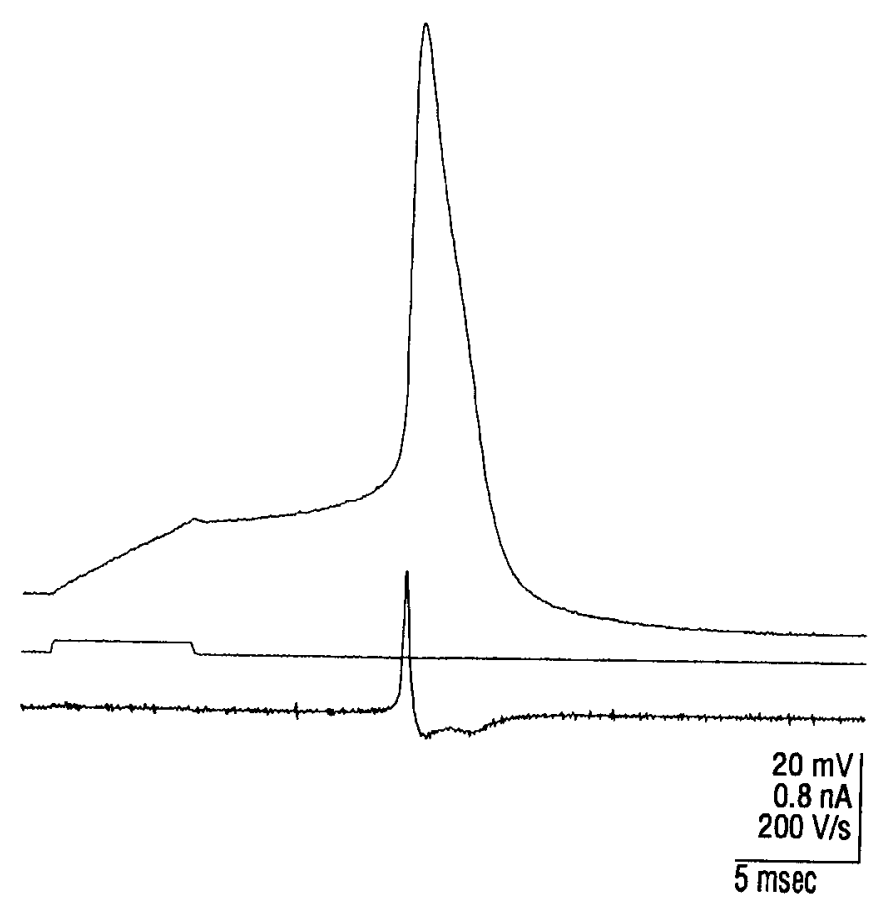

Figure 9. Mesoaccumbens spike shape. A spike is evoked with a brief depolarizing pulse in a mesoaccumbens cell (7 DIV). In this cell, which had a particularly broad action potential, the falling phase shows the shoulder characteristic of these cells in intact preparations. This is further revealed by taking the time derivative (by digital subtraction of adjacent points) of the voltage trace (bottom trace).

(Fig. 10B). Mesoaccumbens cells also showed high-threshold $\mathrm{Ca}^{2+}$ spikes (HTSs) when tested. After TTX had blocked fullsize $\mathrm{Na}^{+}$spikes (Fig. 10C ), increased depolarizing current injection elicited a graded, slower regenerative event, which was blocked by $\mathrm{Cd}^{2+}$ (Fig. 10C $C_{2}$ ). Most mesoaccumbens cells showed both the LTS and the HTS. The LTS could be reliably elicited when cells were fired from $20 \mathrm{mV}$ hyperpolarized in $87 \%$ of retrogradely labeled cells as compared to $33 \%$ in VTA cells. Thus, its incidence closely reflected the percentage of DA cells in the classes of cells considered. Unlike the HTS, the LTS could be elicited without pharmacological manipulation (by hyperpolarization).

Response to hyperpolarization. With hyperpolarizing steps, most (12 of 14) mesoaccumbens cells showed a characteristic sag in the voltage response (Fig. 11A). $\Lambda$ n $I / V$ plot of the pcak response and the final plateau showed a time- and voltagedependent rectification (Fig. $11 B$ ). However, since just over half of VTA cells (10 of 17) also showed anomalous rectification, it could not be used to identify the DA cells.

Autoreceptor response. With perforated-patch recording, we found that most mesoaccumbens cells responded to DA (10 $\mu \mathrm{M})$ or the selective $\mathrm{D}_{2}$ agonist quinpirole $(0.5 \mu \mathrm{M})$ with a slow hyperpolarizing response ( 4 of 5 cells, ranging from 1 to $14 \mathrm{DIV}$; Fig $12 A$ ), while only a fraction of VTA neurons responded ( 3 of 14, 1-16 DIV). A single application was sufficient to induce desensitization persisting for over a minute (not shown). The $\mathrm{D}_{2}$ antagonist sulpiride $(2 \mu \mathrm{M})$ completely and reversibly blocked the quinpirole-induced hyperpolarization. Quinpirole elicited an increased conductance response (Fig. 12B). These results suggest that DA autoreceptors may identify mesolimbic DA cells since DA responses were found in almost exactly the fraction of mesoaccumbens and VTA cells that were dopaminergic. Fig- 

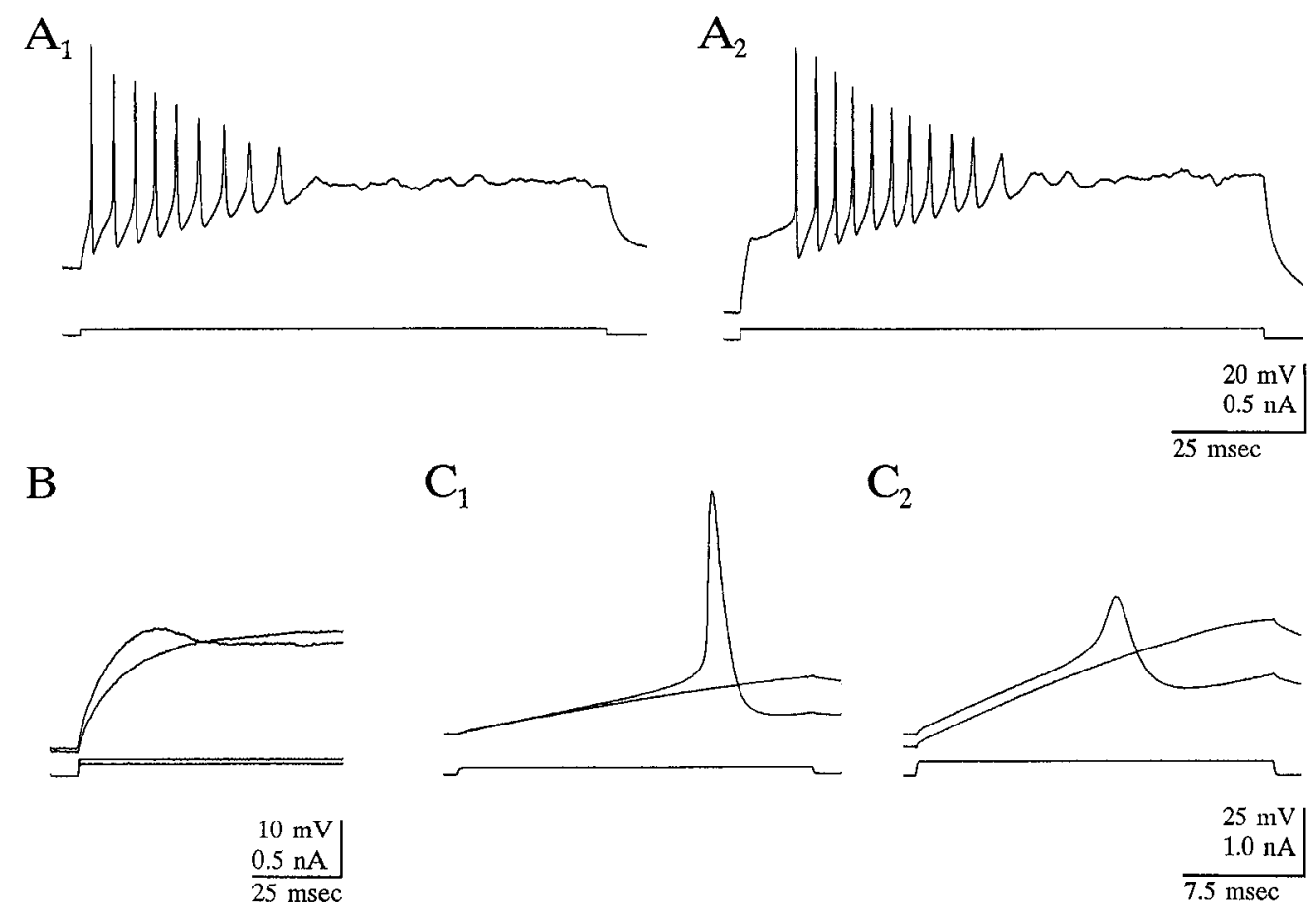

Figure 10. Cell response to depolarizing steps and $\mathrm{Ca}^{2+}$ spikes. $A_{l}$, From rest $(-55 \mathrm{mV})$, strong depolarizations evoke repetitive firing of spikes with prominent afterpotentials (cell is 6 DIV); spikes progressively broaden before showing depolarization inactivation. The remaining membrane potential undulations are probably rhythmic slow depolarizations. $A_{2}$, In the same cell, a stronger depolarization from $-75 \mathrm{mV}$, shows a leading LTS and a pause before firing. Most likely, this pause results from activation of $I_{\mathrm{A}}$, which raises the threshold for $\mathrm{Na}^{+}$spikes, and then rapidly inactivates. This pattern constitutes an electrophysiological signature that correlates with DA status. $B$, LTS. The LTS is more reliably evoked from $-75 \mathrm{mV}$ with a depolarizing step (cell is $9 \mathrm{DIV})$. During a brief cadmium puff $\left(\mathrm{Cd}^{2+}, 4 \mathrm{mM}\right)$, the LTS is blocked. Since input resistance increases in $\mathrm{Cd}^{2+}$, the depolarizing current is reduced. $C$, HTS. The HTS is shown in another cell (4 DIV) with a less prominent LTS. $C_{l}$, Two depolarizing steps from $-55 \mathrm{mV}$ are superimposed before and after TTX $(2 \mu \mathrm{g} / \mathrm{ml})$, which blocks the $\mathrm{Na}^{+}$spike. $C_{2}$, Still in TTX, increased depolarization elicits an HTS. This is blocked by $\mathrm{Cd}^{2+}$, which also slightly hyperpolarizes the cell.

ure 12 also shows spontaneous PSPs usually seen in mesoaccumbens and VTA cells in denser regions of the cultures.

\section{Identification of mesoaccumbens DA cells}

To address which electrophysiological properties were most representative of DA cells, we compared their incidence to the fraction of mesoaccumbens and VTA cells that were $\mathrm{TH}^{+}$(Fig. 13). Broad spikes, hyperpolarizing afterpotentials, anomalous rectification, the LTS, and DA responses werc present in about the same fraction of mesoaccumbens cells as were dopaminergic. However, broad spikes, negative afterpotentials, and anomalous rectification were present in too high of a fraction of VTA cells for these properties to be unique to DA cells. Latency to fire from hyperpolarized levels, the LTS, and DA responses were expressed in fractions of mesoaccumbens and VTA cells close to the incidence of DA cells. A $\chi^{2}$ analysis showed that the incidence of these three properties did not differ significantly from the incidence of DA cells in the two populations. Together, the LTS, latency to fire, and accommodation (observed with step depolarizations from $20 \mathrm{mV}$ hyperpolarized) constitute an electrophysiological signature (compare Fig. $10 A_{2}$ ) of DA status and the $\mathrm{D}_{2}$ autoreceptor response constitutes a pharmacological signature.

\section{Discussion}

Postnatal DA cell culture

DA neurons from the VTA of week-old rats are mature by several indices (Tennyson et al., 1973; Altman and Bayer, 1981;
Voorn et al., 1988; Miura et al., 1990). To achieve successful long-term cultures of these neurons, we found it essential to minimize disruption of neurites during culture preparation (cf. Huettner and Baughman, 1986, 1988), allow neurons physical contact with glia, and employ a modified serum-free medium (cf. di Porzio et al., 1980). A refined dissection of the postnatal VTA produces remarkable increases in the percentages of DA cells (cf. Masuko et al., 1986, 1989). Since the sizes of postnatal neurons are more dimorphic than fetal neurons, gradient separations may be used to purify DA cells (cf. Hatten, 1985). With either of these approaches, we obtain VTA cultures where $50 \%$ of the neurons are dopaminergic. As the percentages of DA neurons increase, however, DA toxicity becomes potentially problematic; indeed, we find DA levels over $10 \mathrm{nM}$ in the medium of established cultures (D. Sulzer and S. Rayport, unpublished HPLC determinations), which is consistent with impublished HPLC determinations), which is consistent with improvement in neuronal survival with the addition of free radical-dissipating enzymes to the medium (cf. Rosenberg, 1988). Importantly, culturing viable postnatal DA neurons facilitates retrograde labeling of a functional subset of cells that are largely dopaminergic. In this way, we are able to ask to what degree the properties of the principal subset of mesolimbic DA neurons, those projecting to the NA, are independent of afferent input and interactions with their targets. Subsequent to our original report (Rayport et al., 1988), several groups have successfully cultured postnatal DA neurons (Lopez-Lozano et al., 1989; Masuko et al., 1989; Cardozo, 1990; Shen et al., 1990; Hama et 
A
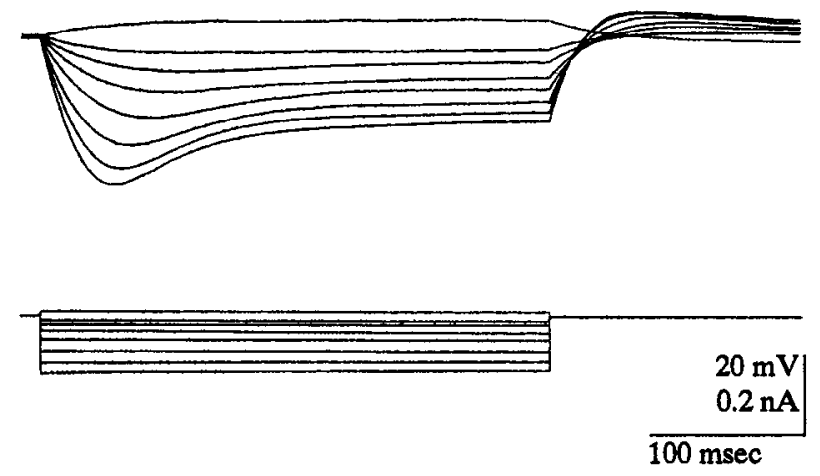

B

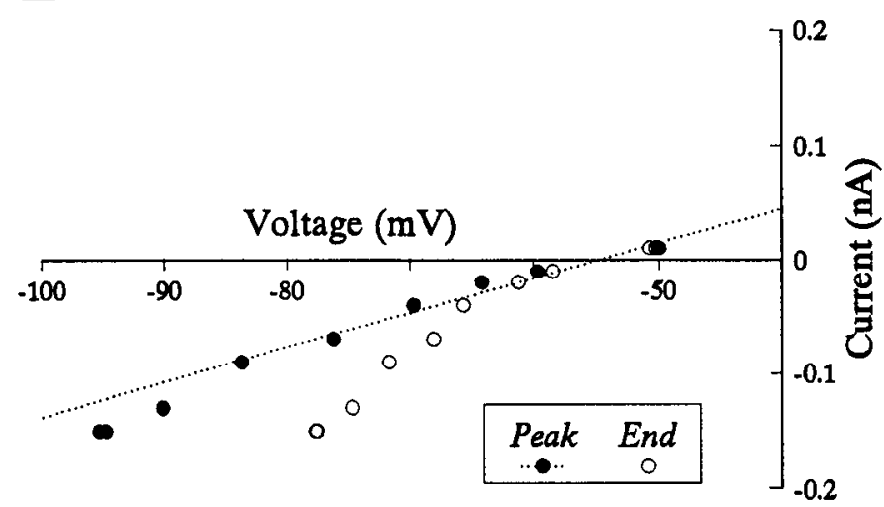

Figure 11. Anomalous rectification. $A$, Current steps from rest (in a cell 12 DIV) reveal a sag in the hyperpolarizing responses with time, increasing with greater hyperpolarization. In other cells, the rebound depolarization triggered spikes (not shown). $B$, Plot of current versus voltage for the peak (solid circles) and end of the plateaus (open circles). The peak (initial) voltage response shows a relatively constant conductance (broken line), with a small voltage-dependent rectification with the largest hyperpolarizations. Time-dependent rectification is far more pronounced, becoming apparent at about $-70 \mathrm{mV}$ and increasing with larger hyperpolarizations.

al., 1991) and have used fluorescent latex microspheres for their identification (Lopez-Lozano et al., 1989; Shen et al., 1990; Silva et al., 1990).

\section{Morphology of cultured VTA DA neurons}

Postnatal DA neurons appear to maintain their morphological characteristics in vitro. Like their in vivo counterparts (Domesick et al., 1983; Grace and Onn, 1989) and cultured fetal DA neurons (Berger et al., 1982), they show a range of soma shapes ranging from multipolar to fusiform. That this similarity in shapes is seen in DA cells under very different conditions suggests that soma shape is determined early in development and intrinsic to the cells. Process outgrowth of fetal DA neurons is comparatively more plastic; differential outgrowth of axons and dendrites depends on whether the cells are grown on homotypic or heterotypic glia (Denis-Donini et al., 1984; Autillo-Touati et al., 1988). Olfactory bulb DA neurons isolated from somewhat more developed perinatal animals, however, show the same stellate process outgrowth regardless of the origin of glial substrate, which could reflect differences between projection neurons and interneurons (Denis-Donini and Estenoz, 1988). Al-
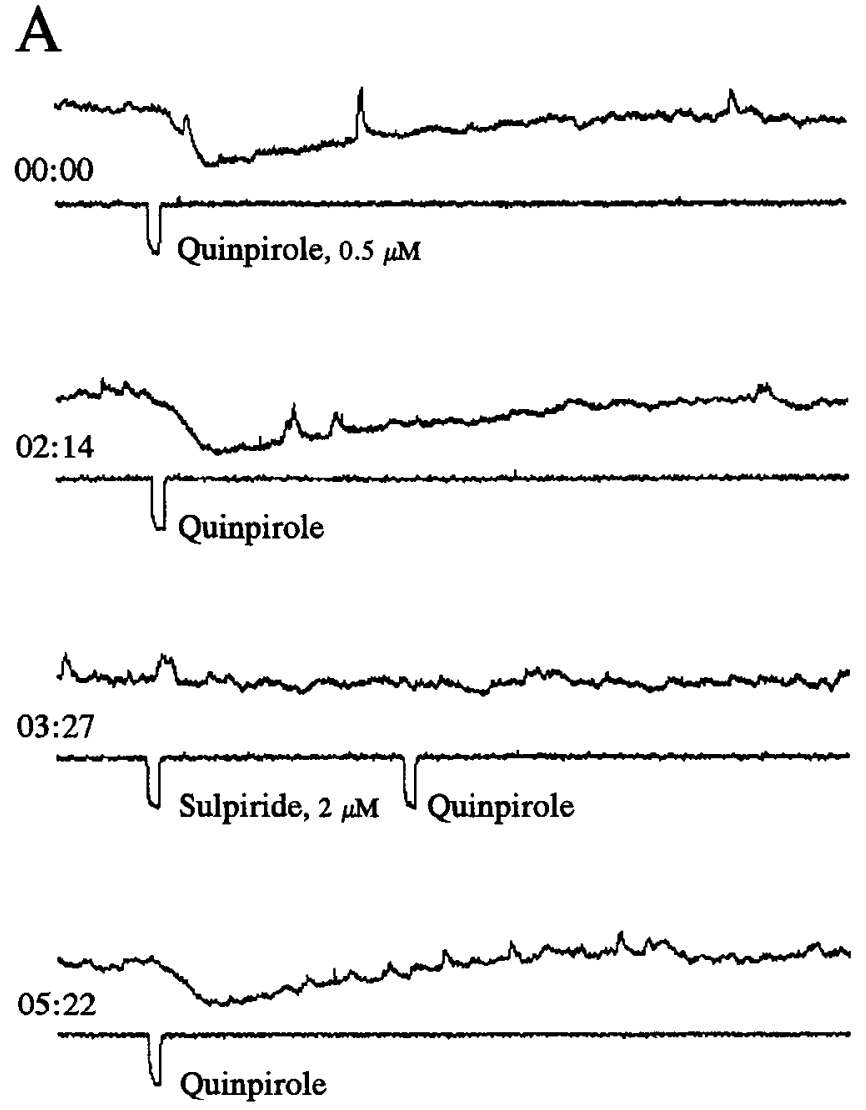

B

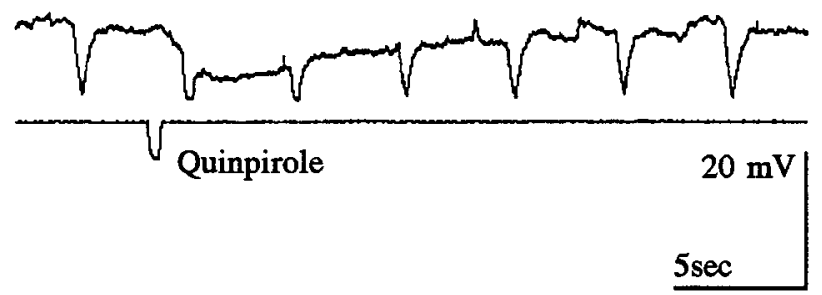

Figure 12. DA autoreceptor response. $A$, Using perforated-patch recording, the $\mathrm{D}_{2}$-sclective agonist quinpirole $(0.5 \mu \mathrm{M})$ evokes a slow hyperpolarization in a mesoaccumbens cell ( 2 DIV). The response desensitizes if quinpirole is applied more often than once a minute (time for each trace is indicated at the left margin). Prior application of sulpiride $(2 \mu \mathrm{M})$ completely blocks the quinpirole response. The frequent, rapid upward deflections on the voltage traces are spontaneous PSPs. Autoreceptor responses of lesser magnitude and reliability are seen with whole-cell recording (not shown). $B$, In the same cell, injection of constant current pulses shows a conductance increase during the quinpirole response.

ternatively, the pattern of process outgrowth might be determined prior to dissociation. Indeed, postnatal DA neurons grown on target area glia (cortical glia), as well as striatal/NA glia (Rayport, Sulzer, and Rajendran, unpublished observations), which should favor axonal growth, show robust dendritic as well as axonal growth. Moreover, postnatal DA neuron process outgrowth is not remarkably different in cultures grown on mesencephalic glia (Rayport, Sulzer, and Rajendran, unpublished observations). Ultrastructurally, cultured DA cells closely resemble their counterparts in the adult brain. Unlike cells from mid-gesta- 


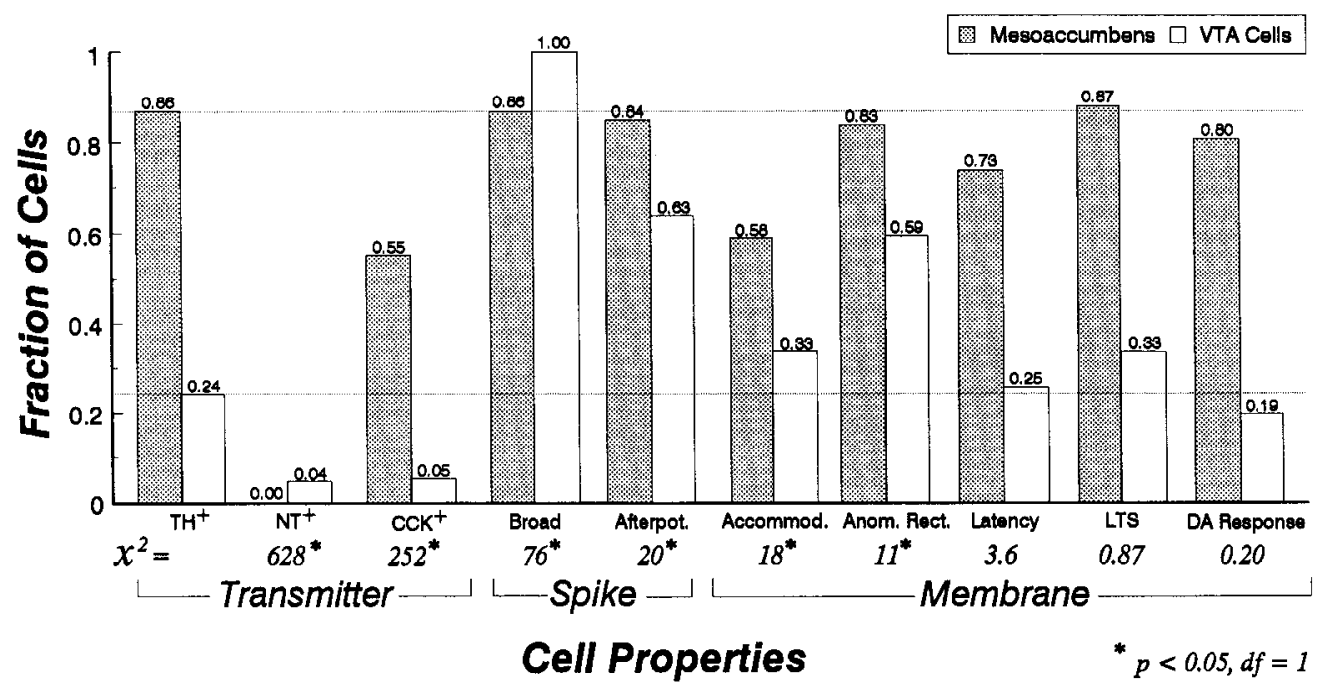

Figure 13. Relationship between TH status and cotransmitter, spike, and membrane properties. Data from mesoaccumbens cells are shown as shaded bars, and from other cells in the culture (VTA cells) as open bars (numbers above the bars are the fraction of cells expressing a given property). By comparing the incidence of a given property with the incidence of TH staining (two horizontal, broken lines), the more reliable indicators of DA status can be assessed. A $\chi^{2}$ analysis was done to assess whether the incidence of cell properties differed from the incidence of TH status in the two cell groups; $\chi^{2}$ values marked with an asterisk differed at the $p<0.05$ level. CCK appears to colocalize with DA in about half of mesoaccumbens cells. NT is not found in mesoaccumbens neurons (although it is present in a minority of VTA neurons). Neither broad spikes (Broad; see Results for criterion) nor negative afterpotentials (Afterpot.) are distinctive for DA cells. Of the membrane properties, the LTS together with latency, and to a lesser degree, accommodation of firing to sustained depolarization (Accommod.), constitute an electrophysiological signature of DA status. Accommodation and latency do not appear to be expressed by all DA cells. Anomalous rectification (Anom. Rect.) is found in the fraction of mesoaccumbens cells that are dopaminergic, but also frequently in VTA cells, and so is not distinctive for DA cells. The autoreceptor response (DA Response) correlates well with $\mathrm{TH}^{+}$status in mesoaccumbens and VTA cells, suggesting that it is a pharmacological signature of DA neurons.

tional fetuses, which do not express TH or DA during the first few days in culture (Berger et al., 1982), postnatal DA cells show robust TH staining and aldehyde-induced histofluorescence from the time of plating on.

Postnatal DA neurons in culture exhibit two levels of $\mathrm{TH}$ expression, as is the case for VTA DA neurons in the adult brain, where darker-staining $\mathrm{TH}^{+}$cells receive more synaptic contacts than lighter-staining $\mathrm{TH}^{+}$cells (Bayer and Pickel, 1990), with lighter-staining cells receiving proportionally more GABAergic contacts (Bayer and Pickel, 1991). Presumably, TH expression is under synaptic control. However, we see the two levels of TH staining in the absence of afferent inputs, in lowdensity cultures where recordings show no synaptic input, and in low-density pure neuronal cultures grown for several days on glass where all processes can be visualized and cell-cell contacts ruled out (Rayport, unpublished observations). Although there are GABAergic neurons in the VTA (Bayer and Pickel, 1991) and in postnatal VTA cultures (Masuko et al., 1989), the lowdensity cultures show that DA cells maintain different levels of TH expression in the absence of synaptic input. How can we reconcile these findings with those in the intact VTA? Possibly, TH expression is not regulated by afferent input alone but can be determined during prenatal development, as we observe differential TH staining in low-density cultures prepared from P1 pups (Rayport, unpublished observations). Alternately, levels of TH staining might identify subclasses of DA cells involved in different neural circuits destined to receive different innervations in the mature VTA.

We expected that because of their relative maturity, postnatal VTA neurons would show a distribution of transmitters matching that in the intact brain. Indeed, $86 \%$ of cultured mesoaccumbens cells are dopaminergic, as compared to $85 \%$ in the intact animal (Swanson, 1982). CCK is present in $56 \%$ of mesoaccumbens cells, indicating that it colocalizes with DA in $48 \%$ of cells $(86 \%$ of $56 \%)$, matching the fraction in the intact animal (Seroogy et al., 1989). NT is not present in our identified mesoaccumbens cells. However, this may also reflect the situation in the intact brain since NT colocalizes with DA in mesocortical DA neurons (Studler et al., 1988; Febvret et al., 1991), mesolimbic DA neurons projecting to the dorsomedial NA (Kalivas and Miller, 1984; Seroogy et al., 1987), and the central amygdaloid nucleus (Seroogy et al., 1987), whereas we labeled DA neurons projecting to the ventral NA.

Taken together, these several morphological observations indicate that cultured postnatal VTA DA cells closely resemble their in vivo counterparts. Most of their morphological properties are expressed in the absence of afferent inputs and independent of continued interactions with target cells, suggesting that they are determined intrinsically. Like their in vivo counterparts, cultured VTA DA cells exhibit a significant morphological heterogeneity. Strikingly, almost the same heterogeneity is seen within the subset of mesoaccumbens DA cells, including the range in soma shapes, levels of TH expression, axodendritic differentiation, and cotransmitter (CCK) expression. Such heterogeneity in a single mesolimbic projection might be consistent with the possibility that $\mathrm{D} \Lambda$ neurons exert more than one synaptic action in target areas (cf. Hattori et al., 1991).

\section{Evidence for synaptic and nonsynaptic DA release}

Cultured postnatal DA neurons further resemble their in vivo counterparts in showing the morphological features associated with the two recognized modes of DA release (Cheramy et al., 1981). This is suggested by the presence of varicosities both on dendrites, where they are distributed uniformly, and on axons, 
where they are distributed distally, resembling the in vivo pattern. Axonal varicosities often closely appose the soma and processes of non-DA cells in culture, showing synaptic specializations at the electron microscopic lcvel consistent with cxocytic release. In contrast, dendrites show no particular association with other cells or processes and do not contain vesicles, rather exhibiting strong aldehyde-induced DA histofluorescence and TH staining, consistent with nonvesicular, neuromodulatory release.

Although promiscuous contacts may form in culture (cf. Schacher et al., 1985), since $\mathrm{TH}^{+}$terminals have been found on both $\mathrm{TH}^{+}$and $\mathrm{TH}^{-}$dendrites in the intact VTA (Bayer and Pickel, 1990), axodendritic synaptic contacts in culture may reflect an accurate reestablishment of normal connections. Since the only cells thought to express DA receptors in the VTA are DA cells (which we confirm electrophysiologically), one may ask what the functional import is of DA contacts on non-DA neurons in the VTA. DA cells are thought to express $\mathrm{D}_{2}$ receptors (Le Moine and Bloch, 1991) and $\mathrm{D}_{3}$ receptors (Bouthenet et al., 1991) exclusively, while $D_{1}$ receptors appear to bc on afferents (Mansour et al., 1990) that are lacking in culture. Possibly synapses on $\mathrm{TH}^{-}$cells are not actually dopaminergic and rather utilize a cotransmitter (cf. Hattori et al., 1991). Alternatively, a small number of $\mathrm{TH}^{-}$cells in the VTA, which have so far gone undetected, may express DA receptors.

\section{Electrophysialogy of mesoaccumbens $D A$ neurons}

By correlating properties expressed by mesoaccumbens cells with the $86 \%$ that are dopaminergic (see Fig. 13), we find that like their in vivo counterparts, DA cells show broad spikes, large hyperpolarizing spike afterpotentials, regular firing when depolarized, anomalous rectification, latency to fire when depolarized from hyperpolarized levels, LTSs, HTSs, accommodation of firing during sustained depolarization, and DA-mediated hyperpolarization. Thus, on most counts, postnatal DA cells in culture resemble thcir in vivo counterparts. Some of these electrophysiological properties are not useful for identification of DA cells since they are also expressed by non-DA cells; these include broad spikes, hyperpolarizing afterpotentials, and anomalous rectification. Other properties that make up an electrophysiological signature (the LTS, latency, and accommodation) or a pharmacological signature (DA responsiveness) are strongly associated with DA status and thus likely identify DA cells.

Like mature DA neurons, their postnatal counterparts show robust DA autoreceptor responses just after plating (1 DIV). This is in contrast to fetal DA neurons that neither respond to DA application (Silva et al., 1988) nor express DA receptors (Daguet et al., 1980) early on in culture, doing so after about 14 DIV (Chiodo and Kapatos, 1987). Time-dependent anomalous rectification is also characteristic of postnatal DA neurons in vitro, while it may be cither absent (Silva et al., 1988) or present (Chiodo and Kapatos, 1987) in fetal DA cultures. That there is no significant change in the expression of active properties over time in culture from 2 to 22 DIV supports the notion that the cells are relatively mature at the time of culture (although they grow in size, accounting for the moderate change in their passive properties).

The lack of spontaneous activity and burst firing, two characteristic properties of adult midbrain DA neurons in vivo, can be explained by the absence of afferent inputs. Burst firing is also lost in moving from brain to slice (cf. Grace and Onn, 1989), suggesting that it is controlled extrinsically (cf. Silva and Bunney, 1988); consistent with this, cultured DA cells never burst. Similarly, the reduced spontaneous activity in culture could also be due to the lack of afferent input. This is supported by the observation that modest tonic depolarization reliably induces pacemaker, but never burst firing. In the more intact preparations, spontaneous activity could arise from tonic excitatory input or continuous depolarization by ambient glutamate (cf. Mereu et al., 1991). Consistent with reduced synaptic input or lower ambient glutamate in culture, input resistances are twice those measured with whole-cell recording in the slice (200-700 MS; Mereu et al., 1991). Membrane time constants are slightly higher than in the slice ( $30 \mathrm{msec}$; Kita et al., 1986; Silva and Bunney, 1988), giving cultured cells a capacitance about two-thirds that of cells in the slice ( $44 \mathrm{vs} 75 \mathrm{pF}$ ). This difference in capacitance (or membrane area) may be due to the limitation in the growth of dendritic trees inherent in two-dimensional cultures. If dendritic conductances are diminished, this might lcad to rcduccd spontaneous activity. Although in vivo spontaneous activity develops over the first few postnatal weeks (Pitts et al., 1990), immaturity of postnatal cells seems a less likely explanation for the observed lack of spontaneous activity since recordings from slices taken from slightly older animals show that DA neurons are spontaneously active (Mereu et al., 1991). Thus, reduced spontaneous activity in culture may be due to diminished depolarizing influences and smaller dendritic conductances.

\section{Limited plasticity and heterogeneity of mesoaccumbens $D A$ neurons}

From the fidelity with which cultured DA cells exhibit the characteristic range of cell properties, one may argue that they show a limited plasticity in culture. Differences in spontaneous activity and burst firing can be related to the absence of afferent inputs. Apparcntly, mesoaccumbens DA cells exhibit a significant heterogeneity manifest in the range in cell shapes, levels of TH staining, and fractional presence of CCK, as well as electrophysiologically in the variability in latency to fire from hyperpolarized levels and accommodation of firing with sustained depolarization.

Variable expression of certain electrophysiological properties in cultured postnatal DA neurons may reflect a previously unappreciated in vivo electrophysiological heterogeneity. It seems less likely that this occurs due to culturing per se, because we find no difference in cell properties between cells grown in a nonenriched serum-containing medium (Rayport et al., 1988) and those raised in serum-free media, or cells examined shortly after plating compared to ones in culture for several weeks; nor did the presence of hetero- or homotypic glia affect properties (Rayport, Sulzer, and Rajendran, unpublished observations). Although there could be a developmental contribution to the observed heterogeneity, with retrograde labeling, where identification depends on an already established projection to the target region, a selection bias would favor more mature cells. Therefore, heterogeneity appears to be intrinsic to these cells and may be expected to impact on their function (cf. Sesack and Bunney, 1987).

In addition to the heterogeneity in DA action now associated with the identification of the several new DA receptor subtypes (Sibley and Monsma, 1992), heterogeneity at the presynaptic 
level may contribute to the controversy over the functions of ccntral DA systems (cf. Rogawski, 1987; Sesack and Bunney, 1987). In the current refinement of the DA hypothesis (cf. Weinberger, 1987; Grace, 1991a), psychotic symptoms result from overactivity in mesolimbic (principally mesoaccumbens) connections. Heterogeneity in cell properties suggests that aberrant activity might arise in a subset of DA neurons. The ability to culture postnatal neurons that largely resemble their in vivo counterparts makes possible the examination of the impact of heterogeneity on DA system function at the level of single synapses.

\section{References}

Ahmed Z, Fellows RE (1987) Determination of the birth date and proliferative state of dissociated cells from fetal rat brain. Dev Brain Res 37:77-87.

Altman J, Bayer SA (1981) Development of the brain stem in the rat. $V$. Thymidine-radiographic study of the time of origin of neurons in the midbrain tegmentum. J Comp Neurol 198:677-716.

Arluison M, Agid Y, Javoy F (1978) Dopaminergic nerve endings in the neostriatum of the rat. 1. Identification by intracerebral injections of 5-hydroxydopamine. Neuroscience 3:657-673.

Autillo-Touati A, Chamak B, Araud D, Vuillet J, Seite R, Prochiantz A (1988) Region-specific neuro-astroglial interactions: ultrastructural study of the in vitro expression of neuronal polarity. J Neurosci Res 19:326-342.

Bayer VE, Pickel VM (1990) Ultrastructural localization of tyrosine hydroxylase in the rat ventral tegmental area: relationship between immunolabeling density and neuronal associations. J Neurosci 10: 2996-3013.

Bayer VE, Pickel VM (1991) GABA-labeled terminals form proportionally more synapses with dopaminergic neurons containing low densities of tyrosine hydroxylase-immunoreactivity in rat ventral tegmental area. Brain Res 559:44-55.

Berger B, di Porzio U, Daguet MC, Gay M, Vigny A, Glowinski J, Prochiantz A (1982) Long-term development of mesencephalic dopaminergic neurons of mouse embryos in dissociated primary cultures: morphological and histochemical characteristics. Neuroscience 7:193-205.

Bouthenet M-L, Souil E, Martres M-P, Sokoloff P, Giros B, Schwartz J-C (1991) Localization of dopamine D3 receptor mRNA in the rat brain using in situ hybridization histochemistry: comparison with dopamine D2 receptor mRNA. Brain Res 564:203-219.

Bunney BS, Walters JR, Roth RH, Aghajanian GK (1973) Dopaminergic neurons: effect of antipsychotic drugs and amphetamine on single cell activity. J Pharmacol Exp Ther 185:560-571.

Cardozo DL (1990) Electrophysiological studies of midbrain dopamine neurons in culture. Soc Neurosci Abstr 16:1044.

Cheramy A, Leviel V, Glowinski J (1981) Dendritic release of dopamine in the substantia nigra. Nature 289:537-542.

Chiodo LA, Kapatos G (1987) Mesencephalic neurons in primary culture: immunohistochemistry and membrane physiology. In: Neurophysiology of dopaminergic systems - current status and clinical perspectives (Chiodo LA, Freeman AS, eds), pp 67-91. Detroit: Lakeshore.

Daguet MC, di Porzio U, Prochiantz A, Kato A, Glowinski J (1980) Release of dopamine from dissociated mesencephalic dopaminergic neurons in primary cultures in absence or presence of striatal target cells. Brain Res 191:564-568.

De la Torre JC (1980) An improved approach to histofluorescence using the SPG method for tissue monoamines. J Neurosci Methods 3:1-5.

Denis-Donini S, Estenoz M (1988) Interneurons versus efferent neurons: heterogeneity in their neurite outgrowth response to glia from several brain regions. Dev Biol 130:237-249.

Denis-Donini S, Glowinski J, Prochiantz A (1984) Glial heterogeneity may define the three-dimensional shape of mouse mesencephalic dopaminergic neurones. Nature 307:641-643.

di Porzio U, Daguet M-C, Glowinski J, Prochiantz A (1980) Effect of striatal cells on in vitro maturation of mesencephalic dopaminergic neurones grown in serum-free conditions. Nature 288:370-373. di Porzio U, Rougon G, Novothny EA, Barker JL (1987) Dopaminergic neurons from embryonic mouse mesencephalon are enriched in culture through immunoreaction with monoclonal antibody to neural specific protein 4 and flow cytometry. Proc Natl Acad Sci USA 84:7334-7338.

Divac I, Mogenson GJ (1990) Long-term retrograde labelling of neurons. Brain Res 524:339-341.

Domesick VB, Stinus L, Paskevich PA (1983) The cytology of dopaminergic and nondopaminergic neurons in the substantia nigra and ventral tegmental area of the rat: a light- and electron-microscopic study. Neuroscience 8:743-765.

Fallon JH (1988) Topographic organization of ascending dopaminergic projections. Ann NY Acad Sci 537:1-9.

Febvret A, Berger B, Gaspar P, Verney C (1991) Further indication that distinct dopaminergic subsets project to the rat cerebral cortex: lack of colocalization with neurotensin in the superficial dopaminergic fields of the anterior cingulate, motor, retrosplenial and visual cortices. Brain Res 547:37-52.

Grace AA (1990) Evidence for the functional compartmentalization of spike generating regions of rat midbrain dopamine neurons recorded in vitro. Brain Res 524:31-41.

Grace AA (1991a) Phasic versus tonic dopamine release and the modulation of dopamine system responsivity: a hypothesis for the etiology of schizophrenia. Neuroscience 41:1-24.

Grace AA (1991b) Regulation of spontaneous activity and oscillatory spike firing in rat midbrain dopamine neurons recorded in vitro. Synapse $7: 221-234$.

Grace AA, Bunney BS (1983a) Intracellular and extracellular electrophysiology of nigral dopaminergic neurons. 1 . Identification and characterization. Neuroscience 10:301-315.

Grace AA, Bunney BS (1983b) Intracellular and extracellular electrophysiology of nigral dopaminergic neurons. 2. Action potential generating mechanisms and morphological correlates. Neuroscience 10: 317-331.

Grace AA, Onn SP (1989) Morphology and electrophysiological properties of immunocytochemically identified rat dopamine neurons recorded in vitro. J Neurosci 9:3463-3481.

Graybiel AM (1990) Neurotransmitters and neuromodulators in the basal ganglia. Trends Neurosci 13:244-254.

Hama T, Kushima Y, Miyamoto M, Kubota M, Takei N, Hatanaka H (1991) Interleukin-6 improves the survival of mesencephalic catecholaminergic and septal cholinergic neurons from postnatal, twoweek-old rats in cultures. Neuroscience 40:445-452.

Hatten ME (1985) Neuronal regulation of astroglial morphology and proliferation in vitro. J Cell Biol 100:384-396.

Hattori T, Takada M, Moriizumi T, Van der Kooy D (1991) Single dopaminergic nigrostriatal neurons form two chemically distinct synaptic types: possible transmitter segregation within neurons. J Comp Neurol 309:391-401.

Heller A, Hutchens JO, Kirby ML, Karapas F, Fernandez C (1979) Stereotaxic electrode placement in the neonatal rat. J Neurosci Methods $1: 41-76$.

Heyer EJ (1984) Electrophysiological study of mammalian neurons from ventral mesencephalon grown in primary dissociated cell culture. Brain Res 310:142-148.

Hökfelt T, Skirboll L, Rehfeld JF, Goldstein M, Markey K, Dann O (1980) A subpopulation of mesencephalic dopamine neurons projecting to limbic areas contains a cholecystokinin-like peptide: evidence from immunohistochemistry combined with retrograde tracing. Neuroscience 5:2093-2124.

Hoorneman (1985) Stereotaxic operation in the neonatal rat; a novel and simple procedure. J Neurosci Methods 14:109-116.

Horn R, Marty A (1988) Muscarinic activation of ionic currents measured by a new whole-cell recording method. J Gen Physiol 92:145159.

Huettner JE, Baughman RW (1986) Primary culture of identified neurons from the visual cortex of postnatal rats. J Neurosci 6:3044-3061.

Huettner JE, Baughman RW (1988) The pharmacology of synapses formed by identified corticocollicular neurons in primary cultures of rat visual cortex. J Neurosci 8:160-175.

Kalivas PW, Miller JS (1984) Neurotensin neurons in the ventral tegmental area project to the medial nucleus accumbens. Brain Res 300:157-160.

Katz LE, Burkhalter A, Dreyer WJ (1984) Fluorescent latex microspheres as a retrograde neuronal marker for in vivo and in vitro studies of visual cortex. Nature 310:498-500. 
Kay AR, Wong RKS (1986) Isolation of neurons suitable for patchclamping from adult mammalian central nervous systems. J Neurosci Methods 16:227-238.

Kay AR, Wong RKS (1987) Calcium current activation kinetics in isolated pyramidal neurones of the CAI region of the mature guineapig hippocampus. J Physiol (Lond) 392:603-616.

Kita T, Kita H, Kitai ST (1986) Electrical membrane properties of rat substantia nigra compacta neurons in an in vitro slice preparation. Brain Res 372:21-30.

Lacey MG, Mercuri NB, North RA (1987) Dopamine acts on D2 receptors to increase potassium conductance in neurones of the rat substantia nigra zona compacta. J Physiol (Lond) 392:397-416.

Lacey MG, Mercuri NB, North RA (1988) On the potassium conductance increase activated by GABA-B and dopamine $D 2$ receptors in rat substantia nigra neurones. J Physiol (Lond) 401:437-453.

Lacey MG, Mercuri NB, North RA (1989) Two cell types in rat substantia nigra zona compacta distinguished by membrane properties and the actions of dopamine and opioids. J Neurosci 9:1233-1241.

Le Moine C, Bloch B (1991) Rat striatal and mesencephalic neurons contain the long isoform of the D2 dopamine receptor mRNA. Mol Brain Res 10:283-289.

Llinás R, Greenfield SA, Jahnsen H (1984) Electrophysiology of pars compacta cells in the in vitro substantia nigra-a possible mechanism for dendritic release. Brain Res 294:127-132.

Lopez-Lozano JJ, Notter MFD, Gash DM, Leary JF (1989) Selective flow cytometric sorting of viable dopamine neurons. Brain Res 486: 351-356.

Mansour A, Meador-Woodruff JH, Bunzow JR, Civelli O, Akil H, Watson SJ (1990) Localization of dopamine D2 receptor mRNA and D1 and D2 receptor binding in the rat brain and pituitary: an in situ hybridization-receptor autoradiographic analysis. J Neurosci 10: $2587-2600$

Masuko S, Nakajima Y, Nakajima S, Yamaguchi K (1986) Noradrenergic neurons from the locus ceruleus in dissociated cell culture: culture methods, morphology, and electrophysiology. J Neurosci 6: 3229-3241

Masuko S, Nakajima S, Nakajima Y (1989) Dopaminergic neuron cultures from the substantia nigra and the ventral tegmental area. Soc Neurosci Abstr 15:819.

Masurovsky EB, Bunge RP (1968) Fluoroplastic coverslips for longterm nerve tissue culture. Stain Technol 43:161-165.

Matsuda Y, Fujimura K, Yoshida S (1987) Two types of neurons in the substantia nigra pars compacta studied in a slice preparation. Neurosci Res 5:172-179.

McCarthy KD, de Vellis $J$ (1980) Preparation of separate astroglial and oligodendroglial cell cultures from rat cerebral tissue. J Cell Biol 85:890-902.

Mereu G, Costa E, Armstrong DM, Vicini S (1991) Glutamate receptor subtypes mediate excitatory synaptic currents of dopamine neurons in midbrain slices. J Neurosci 11:1359-1366.

Miura K, Sakai M, Komori K, Furune S, Watanabe K, Nagatsu I (1990) Semiquantitative immunohistochemical study on normal development of nigrostriatal dopaminergic neurons in the mouse brain. Biog Amines 7:483-491.

Mueller AL, Brodie MS (1989) Intracellular recording from putative dopamine-containing neurons in the ventral tegmental area of Tsai in a brain slice preparation. J Neurosci Methods 28:15-22.

Oades RD, Halliday GM (1987) Ventral tegmental (A10) system: neurobiology. 1. Anatomy and connectivity. Brain Res Rev 12:117165.

Phifer CB, Terry LM (1986) Use of hypothermia for general anesthesia in preweanling rodents. Physiol Behav 38:887-890.

Pitts DK, Freeman AS, Chiodo LA (1990) Dopamine neuron ontogeny: electrophysiological studies. Synapse 6:309-320.

Prochiantz A, di Porzio U, Kato A, Berger B, Glowinski J (1979) In vitro maturation of mesencephalic dopaminergic neurons from mouse embryos is enhanced in presence of their striatal target cells. Proc Natl Acad Sci USA 76:5387-5391.

Rayport S, Monaco J, Sawasdikosol S (1988) Identified mesoaccumbens dopamine neurons in vitro. Soc Neurosci Abstr 14:932.

Rayport S, Sulzer D, Batson D (1989) Purified cultures of ventral tegmental area (VTA) dopamine neurons. Soc Neurosci Abstr 15:819.

Rayport S, Sulzer D, Shi W-X (1990) Heterogeneity of mesoaccumbens dopamine neurons. Soc Neurosci Abstr 16:1049.

Rogawski MA (1987) New directions in neurotransmitter action: dopamine provides some important clues. Trends Neurosci 10:200-205.
Rosenberg PA (1988) Catecholamine toxicity in cerebral cortex in dissociated cell culture. J Neurosci 8:2887-2894

Rosenberg PA, Aizenman E (1989) Hundred-fold increase in neuronal vulnerability to glutamate toxicity in astrocyte-poor cultures of rat cerebral cortex. Neurosci Lett 103:162-168.

Rousselet A, Fetler L, Chamak B, Prochiantz A (1988) Rat mesencephalic neurons in culture exhibit different morphological traits in the presence of media conditioned on mesencephalic or striatal astroglia. Dev Biol 129:495-504.

Schacher S, Rayport S, Ambron RT (1985) Giant Aplysia neuron R2 reliably forms strong chemical connections in vitro. J Neurosci 5: $2851-2856$.

Seroogy KB, Mehta A, Fallon JH (1987) Neurotensin and cholecystokinin coexistence within neurons of the ventral mesencephalon: projections to forebrain. Exp Brain Res 68:277-289.

Seroogy KB, Ceccatelli S, Schalling M, Hökfelt T, Frey P, Walsh J, Dockray G, Brown J, Buchan A, Goldstein M (1988) A subpopulation of dopaminergic neurons in rat ventral mesencephalon contains both neurotensin and cholecystokinin. Brain Res 455:88-98.

Seroogy KB, Dangaran K, Lim S, Haycock JW, Fallon JH (1989) Ventral mesencephalic neurons containing both cholecystokinin- and tyrosine hydroxylase-like immunoreactivities project to forebrain regions. J Comp Neurol 279:397-414.

Sesack SR, Bunney BS (1987) Central dopaminergic systems: neurophysiology and electrophysiological pharmacology. In: Handbook of schizophrenia, Vol 2, Neurochemistry and neuropharmacology of schizophrenia (Henn FA, DeI isi LE, eds), pp 149-178. New York: Elsevier.

Sesack SR, Pickel VM (1990) In the rat medial nucleus accumbens, hippocampal and catecholaminergic terminals converge on spiny neurons and are in apposition to each other. Brain Res 527:266-279.

Shen R, Chiodo LA, Kapatos G (1990) Retrogradely labeled dopaminergic neurons in primary cultures from neonatal rats. Soc Neurosci Abstr 16:1046.

Shepard PD, German DC (1988) Electrophysiological and pharmacological evidence for the existence of distinct subpopulations of nigrostriatal dopaminergic neuron in the rat. Neuroscience 27:537-546.

Sibley DR, Monsma FJ (1992) Molecular biology of dopamine receptors. Trends Pharmacol Sci 13:61-69.

Siegel S (1956) Nonparametric statistics for the behavioral sciences. New York: McGraw-Hill.

Silva NL, Bunney BS (1988) Intracellular studies of dopamine neurons in vitro: pacemakers modulated by dopamine. Eur J Pharmacol 149: 307-315.

Silva NL, Mariani AP, Harrison NL, Barker JL (1988) 5,7-Dihydroxytryptamine identifies living dopaminergic neurons in mesencephalic cultures. Proc Natl Acad Sci USA 85:7346-7350.

Silva NL, Pechura CM, Barker JL (1990) Postnatal rat nigrostriatal dopaminergic neurons exhibit five types of potassium conductances. J Neurophysiol 64:262-272.

Smith AD, Bolam JP (1990) The neural network of the basal ganglia as revealed by the study of synaptic connections of identified neurones. Trends Neurosci 13:259-265.

Studler JM, Kitabgi P, Tramu G, Herve D, Glowinski J, Tassin JP (1988) Extensive co-localization of neurotensin with dopamine in rat meso-cortico-frontal dopaminergic neurons. Neuropeptides 11: 95-100.

Sulzer D, Rayport S (1990) Amphetamine and other psychostimulants reduce $\mathrm{pH}$ gradients in midbrain dopaminergic neurons and chromaffin granules: a mechanism of action. Neuron 5:797-808.

Swanson LW (1982) The projections of the ventral tegmental area and adjacent regions: a combined fluorescent retrograde tracer and immunofluorescence study in the rat. Brain Res Bull 9:321-353.

Tennyson VM, Mytilineou C, Barrett RE (1973) Fluorescence and electron microscopic studies of the early development of the substantia nigra and area ventralis tegmenti in the fetal rabbit. J Comp Neurol 149:233-258.

Tepper JM, Sawyer SF, Groves PM (1987) Electrophysiologically identified nigral dopaminergic neurons intracellularly labeled with HRP: light-microscopic analysis. J Neurosci 7:2794-2806.

Thierry AM, Deniau JM, Herve D, Chevalier G (1980) Electrophysiological evidence for non-dopaminergic mesocortical and mesolimbic neurons in the rat. Brain Res 201:210-214.

Voorn P, Kalsbeek A, Jorritsma-Byham B, Groenwegen HJ (1988) The pre- and postnatal development of the dopaminergic cell groups 
in the ventral mesencephalon and the dopaminergic innervation of the striatum of the rat. Ncuroscience 25:857-887.

Wang RX (1981) Dopaminergic neurons in the rat ventral tegmental area. I. Identification and characterization. Brain Res Rev 3:123-140. Weinberger DR (1987) Implications of normal brain development for the pathogenesis of schizophrenia. Arch Gen Psychiatry 44:660-669.
Yamamoto M, Steinbusch HWM, Jessell TM (1981) Differentiated properties of identified serotonin neurons in dissociated cultures of embryonic rat brain stem. J Cell Biol 91:142-152.

Yung WH, Häusser MA, Jack JJB (1991) Electrophysiology of dopaminergic and non-dopaminergic neurones of the guinea-pig substantia nigra pars compacta in vitro. J Physiol (Lond) 436:643-667. 